\title{
The impact of psychological ownership on employee retention in mergers and acquisitions
}

\author{
William Y. Degbey \\ Department of Marketing \& International Business \\ Turku School of Economics, \\ University of Turku, \\ FI-20014 \\ Finland \\ william.degbey@utu.fi \\ Peter Rodgers \\ Leicester University School of Business, \\ University of Leicester, \\ LE1 7RH \\ UK \\ pwr3@leicester.ac.uk \\ Momo D. Kromah \\ UQ Business School, \\ University of Queensland \\ St Lucia, QLD 4072 \\ Australia \\ m.kromah@uq.edu.au \\ Yaakov Weber \\ School of Business Administration \\ College of Management \\ Rishon Lezion, Israel \\ yweber@bezeqint.net
}

Rights statement: This is the authors' version of the article that has been accepted for publication in Human Resource Management Review and undergone full peer review but has not been through the copyediting, typesetting, pagination and proofreading process, which may lead to differences between this version and the Version of Record.

Please cite this article as: Degbey, W.Y., Rodgers, P., Kromah, M.D., \& Weber, Y. (in press). The impact of psychological ownership on employee retention in mergers and acquisitions, Human Resource Management Review. DOI: https://doi.org/10.1016/j.hrmr.2020.100745 


\begin{abstract}
Research has demonstrated that turnover rates among employees and executives in the acquired firm are much higher during an M\&A event. Recent empirical and review articles on M\&A have also shown that employee retention/turnover can best be understood by looking at psychological attributes and perceptions of M\&As, thus drawing significant attention to the psychological and 'human' side voids to theoretically exploit and enhance understanding of people-related problems in M\&A endeavors. In this article, we develop a moderated mediation model and propose that acquired firm employees' psychological ownership is positively related to acquired firm employees' retention through the direct and mediating effects of employees' commitment and involvement in M\&A. We also propose that the effect of acquired firm employees' psychological ownership on employees' commitment and involvement and, ultimately, acquired firm employees' retention is moderated by loss of acquired firm autonomy. We also discuss implications for theory and practice, as well as future research directions of such an employees' psychological ownership perspective on retention effects.
\end{abstract}

Keywords: Psychological ownership; Retention/turnover; Employee; Commitment \& Involvement; Mergers \& Acquisitions

\title{
1. Introduction
}

"When managers talk about ownership, what they typically want to instill is not

financial ownership but psychological ownership - a feeling on the part of the employees that they have a responsibility to make decisions that are in the long term interest of the company" (O'Reilly, 2002, p. 19).

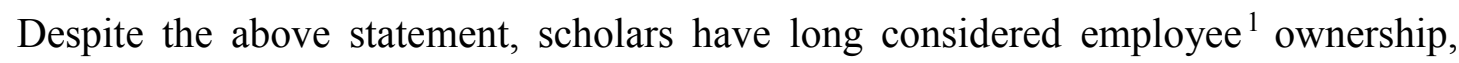
particularly stock ownership, as a critical attitudinal and behavioral barometer for improved employee retention, thus creating a mutual interest with the employer for the benefit of both parties (e.g. Long, 1978). Similarly, firms undergoing mergers and

\footnotetext{
${ }^{1}$ We treat the term 'employee' from a unitary perspective to represent both managerial and nonmanagerial employees of the acquired organization, as the concept of psychological ownership can operate in the presence or absence of legal ownership (Van Dyne \& Pierce, 2004; Wilpert, 1991), and/or the psychological experience of ownership for the organization may not only be experienced, for example, by those employees who own stocks in a firm or form part of the top management team (cf. Rousseau \& Shperling, 2003).
}

Rights statement: This is the authors' version of the article that has been accepted for publication in Human Resource Management Review and undergone full peer review but has not been through the copyediting, typesetting, pagination and proofreading process, which may lead to differences between this version and the Version of Record. 
acquisitions (M\&As), have predominantly focused on legal/formal ownerships - while crudely excluding the psychological aspect-for exercising control and making key M\&A decisions such as the retention of acquired firm employees, as well as the overall enhancement of value creation and performance improvement of M\&As (e.g. Degbey, 2015; Degbey \& Ellis, 2017, 2019; Degbey \& Hassett, 2016; Gomes, Weber, Brown, \& Tarba, 2011; Krug \& Shill, 2008). However, the success of M\&As remains a challenge to executives and employees (Gomes, Angwin, Weber \& Tarba, 2013; Weber, Tarba, \& Öberg, 2014) due to continuous high failure rates found in various academic disciplines and surveys by consulting firms such as BCG, KPMG and Mckinsey (e.g. Christofferson, McNish, \& Sias, 2004; Kelly, Cook, \& Spitzer, 2003; Schoenberg, 2006; Thanos \& Papadiakis, 2012). One of the reasons is the high rate of acquired executives and key talents turnover following M\&A. Scholars and practitioners have found that M\&A events often foreshadow higher turnover of employees, particularly from the acquired firm (Ahammad, Glaister, Weber, \& Tarba, 2012; Hambrick \& Cannella, 1993; Krug \& Aguilera, 2005; Zhang, Ahammad, Tarba, Cooper, Glaister, \& Wang, 2015). Relatedly, despite the predominant focus on financial and strategic explanations of extant M\&A studies, growing evidence suggests that onethird and one-half of all M\&A failures are attributable to people problems (e.g. Cartwright \& Cooper, 1993; Krug, Wright, \& Kroll, 2014; Weber et al., 2012). While there is evidence that cultural differences, a given factor, create this turnover, executives and especially human resource managers, cannot simply change this cause and effect relationship. As noted, these practitioners and researchers have limited

Rights statement: This is the authors' version of the article that has been accepted for publication in Human Resource Management Review and undergone full peer review but has not been through the copyediting, typesetting, pagination and proofreading process, which may lead to differences between this version and the Version of Record. 
knowledge about other factors that directly, and through mediation, influence turnover and other related phenomena (Weber, 2012).

This paper argues that the lack of understanding on what causes the high turnover that leads to poor M\&A performance is at least partly due to an incomplete conceptualization of the psychological mechanisms through which turnover occurs in M\&A. This indicates that there are several gaps in the current state of the art. Literature reviews about the mixed results on the effects of cultural differences on M\&A performance point out that this is due to omission of important variables (Sarala, Junni, Cooper, \& Tarba, 2016; Tarba, Ahammad, Junni, Stokes, \& Morag, 2019; Weber, 2012; Weber, Tarba, \& Reichel, 2011; Weber \& Drori, 2011; Weber, Tarba, \& Reichel, 2009). Furthermore, the role of HRM in M\&As requires further theoretically grounded examination (Weber \& Fried, 2011; Weber, 2012). In other words, the factors and HR managerial actions for intervention during the post-merger integration process to prevent, or at least minimize, post-merger turnover remain unclear (Gomes et al., 2013; King et al., 2019; Weber, 2012; Weber \& Tarba, 2010). Finally, this paper asserts that employees' psychological ownership is an important asset of the acquired company that, given some moderators, influences turnover through employees' commitment and involvement. As such, it can act as an important tool for HR managers to prevent or at least to minimize post-merger turnover. This paper moves from the focus on the effects of cultural differences on turnover to explore the mechanisms and interrelationships among important variables that influence retention. More specifically, the paper seeks to address the inadequate understanding of employee retention in M\&A by identifying

Rights statement: This is the authors' version of the article that has been accepted for publication in Human Resource Management Review and undergone full peer review but has not been through the copyediting, typesetting, pagination and proofreading process, which may lead to differences between this version and the Version of Record. 
the key underlying psychological phenomenon and mechanisms (in the form of crucial mediators and moderators) that arrest—or bolster- this retention effect.

In this article, such psychological phenomenon is founded on the psychology of possession (the feeling that an object, entity, or idea is 'MINE' or 'OURS'), which constitutes the foundation of psychological ownership (Furby, 1978). The psychology literature has long recognized M\&A activity as a major and complex process of organizational change (Humpal, 1971), with the potential to profoundly impact the lives of employees (Cartwright \& Cooper 1990, 1993). For example, frequent attitudinal or behavioral expression of acquiring firm executives and/or managers - e.g. "it is 'our' newly acquired firm, we bought them"- toward members of the acquired firm evokes a sense of possession. Indeed, scholars posit that psychological ownership is ubiquitous, as it can occur in relation to legal/formal ownership or in its absence and can pertain to tangible or intangible objects (Van Dyne \& Pierce, 2004; Wilpert, 1991). Therefore, such ownership is found to demonstrate positive relationships with measures of organizational performance (Conte \& Tannenbaum, 1978; Hammer, Landau, \& Stem, 1981; Long, 1978). A critical assumption, which underpins its tendency to produce positive attitudinal and behavioral outcomes, is that formal/legal employee ownership is not necessary for ownership feelings and behavioral alterations to emerge (e.g. Pierce, Kostova, \& Dirks, 2001). Thus, we argue that psychological ownership is a vital asset of the acquired firm but can be destroyed in the M\&A process. The role of HR is thus critical in protecting this asset to better understand employees' responses following M\&A events. The adoption of this psychological perspective in this article

Rights statement: This is the authors' version of the article that has been accepted for publication in Human Resource Management Review and undergone full peer review but has not been through the copyediting, typesetting, pagination and proofreading process, which may lead to differences between this version and the Version of Record. 
may also serve to complement the prevailing macro-level interest especially in M\&A research (cf. Lee, Kim, Kim, Kwon, \& Cho, 2013).

Bearing in mind the research voids mentioned above and in light of the paucity of research on the key underlying psychological mechanisms that influence retention, the aim of this article is to develop a conceptual model that shows that employees' psychological ownership in M\&A provides a clear-cut theoretical basis for understanding the inherent challenge of acquired firm employees' retention post-M\&A. That is, the possessive attribute of psychological ownership distinguishes it from other related concepts such as commitment, identification or satisfaction in M\&A whilst simultaneously allowing it to deepen our understanding of employee attitudes and behavior beyond existing constructs (cf. Van Dyne \& Pierce, 2004). In other words, this article's conceptual arguments differ from prior studies that establish a relationship between related concepts of psychological ownership (e.g. organizational commitment - Hassett, 2012, Mathieu \& Zajac, 1990; organizational identification - Kroon, Noorderhaven, \& Leufkens, 2009; occupational identification - Kroon \& Noorderhaven, 2018) and M\&A outcomes. We emphasize feelings of possession as the unique conceptual core of human experience particularly in the context of a critical organizational change (M\&A in this case).

Specifically, an important contribution of the present article is the development of a conceptual model and testable propositions that draw on the concept of psychological ownership to inform the literature on retention/turnover of acquired firm employees, and thus advancing scholarship in the HR-stream of M\&A performance research. In

Rights statement: This is the authors' version of the article that has been accepted for publication in Human Resource Management Review and undergone full peer review but has not been through the copyediting, typesetting, pagination and proofreading process, which may lead to differences between this version and the Version of Record. 
addition, we highlight the effects of employee commitment and involvement, as well as the moderating effect of acquired firm autonomy removal on employee retention in M\&A. More broadly, we contend that our moderated mediation model (see also, Preacher, Rucker, \& Hayes, 2007) contributes to the broad organizational behavior school of thought in M\&A (e.g. Birkinshaw et al., 2000; Haspeslagh \& Jemison, 1991).

Our theorized relationships are summarized in Figure 1.

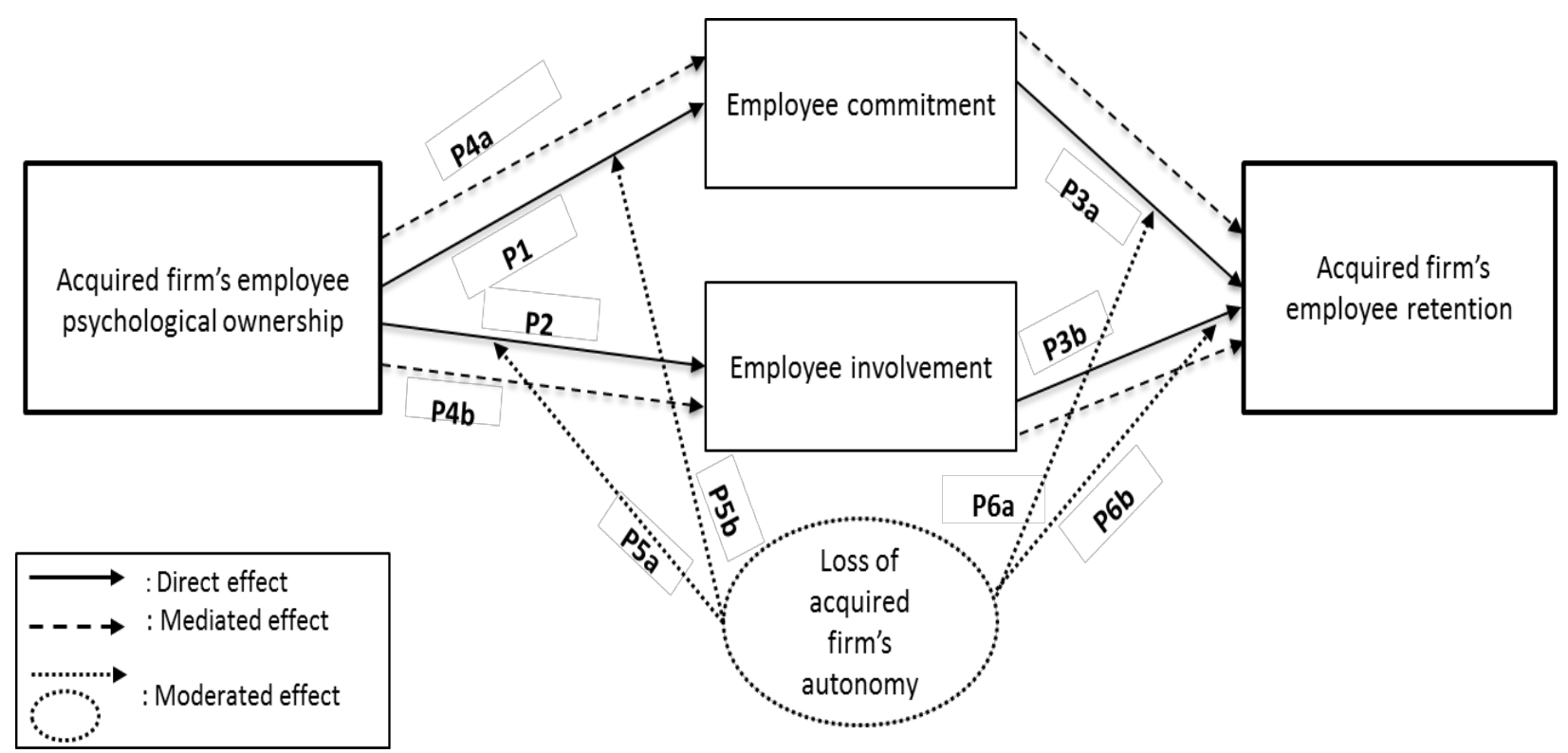

Figure 1 Impact of psychological ownership on employee retention in M\&A.

To improve the conceptualization of the psychological mechanisms through which turnover occurs in M\&A, we suggest that psychological ownership is an important asset that may help enhance our understanding of employee retention-strengthening (or employee turnover-weakening) following M\&A, and certain effects unaccounted for in extant related models that attempt to explicate how M\&A can undermine or strengthen employee retention. Our model thus provides practitioners and scholars with a

Rights statement: This is the authors' version of the article that has been accepted for publication in Human Resource Management Review and undergone full peer review but has not been through the copyediting, typesetting, pagination and proofreading process, which may lead to differences between this version and the Version of Record. 
“psychological ownership" approach for deciphering and managing how to strengthen acquired firm employee retention or minimize their turnover in M\&A. For academics, this could mean testing our proposed conceptual model. For M\&A practitioners, this could mean creating awareness for identifying employees' psychological ownership and its mechanisms, particularly in the acquired firm from multiple sources and hierarchical levels to foster the retention of employees during times of critical organizational events, such as M\&A.

The rest of the paper is structured as follows. Firstly, we review prior academic work on turnover in M\&A to highlight the inconsistent findings, contradictions and mixed results, as well as a review on the removal of acquired firm's autonomy following an M\&A. Secondly, we present and discuss the concept of 'psychological ownership' briefly with explicit elaborations of behavioral issues. Thirdly, we develop testable propositions based on Figure 1's key variables-namely, psychological ownership, commitment and involvement, loss of autonomy, and employee retention. Finally, we provide discussion and conclusions, and also note some limitations/boundary conditions and specify directions for further research.

\section{Literature review on turnover, autonomy removal and psychological ownership}

\subsection{Employee turnover and autonomy removal in M\&A}

Turnover may best be understood by looking at employees' and executives' psychological attributes and perceptions of M\&A (Krug et al., 2014). Research has demonstrated that turnover rates among employees and executives in the acquired firm

Rights statement: This is the authors' version of the article that has been accepted for publication in Human Resource Management Review and undergone full peer review but has not been through the copyediting, typesetting, pagination and proofreading process, which may lead to differences between this version and the Version of Record. 
are much higher during an M\&A process (Cannella \& Hambrick, 1993; Krishnan et al., 1997; Krug \& Hegarty, 2001; Lubatkin et al., 1999; Walsh, 1989; Walsh \& Ellwood, 1991). For example, the findings of Krug and Hegarty (1997) regarding acquisitions of US firms show that the turnover of acquired firm managers rose to $76 \%$ by the fifth year following the M\&A. Similarly, Walsh (1988) demonstrated that $25 \%$ of key employees left the company in the first year after an M\&A. In addition, Walsh (1988) found that acquired firms can expect to see approximately two-thirds of their executives depart within five years of acquisition. This finding stands in stark contrast to the figures highlighting only $8 \%$ of managers leaving each year in firms, which have not been acquired. Further, Bergh (2001) explored the relationship between retention of an acquired firm's key employees/executives and the probability of acquired firm divesture, and found that the higher the retention of incumbent key employees, the lower the probability of divesture of the acquired firm. Hence, suggesting that retention of key employees has a significant impact on the success of the M\&A (e.g. Ranft \& Lord, 2000). Furthermore, Cannella and Hambrick (1993) studied 96 large, publicly traded acquired U.S. companies and found that the performance of these firms was most detrimentally affected when employees/executives left following the M\&A, indicating their role as important organizational resources, which if not retained can lead to consequential breaks within internal organizational processes, which in turn can lead to instability within the firm. Also, the study of Krishnan et al. (1997) found that in M\&As in which there were high levels of complementarity between both sets of employees/executives, integration into the new organizational setting was easier and

Rights statement: This is the authors' version of the article that has been accepted for publication in Human Resource Management Review and undergone full peer review but has not been through the copyediting, typesetting, pagination and proofreading process, which may lead to differences between this version and the Version of Record. 
led to lower post-acquisition employee/executive turnover rates and higher postacquisition performance. These aforementioned studies (i.e., Cannella \& Hambrick, 1993; Bergh, 2001; Krishnan et al., 1997; Walsh, 1988), which subscribe essentially to a resource-based perspective, advance that acquired firm employees/executives are valuable resources (i.e. they possess valuable firm-specific knowledge and capabilities - see Barney, 1988) that require retention in order to achieve higher postacquisition performance (Butler, Perryman, \& Ranft, 2012).

In contrast to the above research and findings, other scholars have sought to explain the linkages between employee/executive turnover and post-acquisition performance via the perspectives of agency theory and the market for corporate control (Manne, 1965), and thus argue that acquired employee/executive turnover is desirable for the reason that M\&As serve to discipline inefficient/incompetent employees/executives (Jensen \& Ruback, 1983). In other words, the failure of employees/executives to improve firm performance usually results in outside firms taking over control of the organization and getting rid of incompetent management in an effort to improve performance (Jarrell et al., 1988; Nyberg et al., 2010). In support of the latter arguments, a similar stream of literature concludes that there is a positive relationship between turnover rates of top employees/executives and low organization profits, financial difficulties and poor performance on stock markets (Coughlan \& Schmidt, 1985; DeAngelo \& DeAngelo, 1985; Firth, Fung, \& Rui, 2006). Even though this perspective has remained a dominant one for more than 25 years, subsequent studies have questioned this view of employee/executive turnover as being indeed a desirable

Rights statement: This is the authors' version of the article that has been accepted for publication in Human Resource Management Review and undergone full peer review but has not been through the copyediting, typesetting, pagination and proofreading process, which may lead to differences between this version and the Version of Record. 
M\&A outcome. For example, Walsh and Ellwood (1991) found contradictory evidence highlighting no significant relationship between poor pre-acquisition performance and post-acquisition turnover. Similarly, Davis and Stout (1992) in a study of takeover bids between 1980 and 1990 found that most acquired firms were well performing firms (i.e. outperform their competitors before acquisition) —indicating that they have something valuable acquirers desire. Moreover, findings of Walsh and Kosnik (1993, p. 671) about corporate raiders similarly concluded that there is "only evidence of market discipline among target firms and competitors with sustained histories of poor performance". Furthermore, Krug et al. (2014) note that turnover, in general, is high in acquired firms with both good and bad performance results, and thus poor pre-acquisition performance does not fully explain why employees/executives depart at such high rates postacquisition.

Besides these inconsistent findings, contradictions and mixed results, essentially dominated by resource-based view and agency theory (and market for corporate control) explanations, other scholars, to a less extent, also have attempted to explain the linkage between employee turnover/retention, its antecedents and post-acquisition performance using industry and country perspectives (Krug et al., 2014). For example, McNamara et al. (2008) highlight from an industry perspective how firms, which acquire at the beginning of a merger wave (i.e. early movers) generally perform better than late movers, as they are able to identify high-value firms to be acquired relatively cheaply. Such a finding may have a consequence for firms to restructure assets involving the removal of top managers from the acquired firm. In addition, early

Rights statement: This is the authors' version of the article that has been accepted for publication in Human Resource Management Review and undergone full peer review but has not been through the copyediting, typesetting, pagination and proofreading process, which may lead to differences between this version and the Version of Record. 
research focused on the issue of relatedness argued that acquiring firms were more likely to remove top managers who operated in similar industries (Pitts, 1976), whilst retaining top managers in unrelated industries due to the expected knowledge they held from other industries. However, comparatively recent research (e.g. Hambrick \& Cannella, 1993; Walsh, 1988) demonstrates that industry relatedness is a weak direct predictor of turnover. Moreover, Krug and Nigh (1998) argued that turnover depends on the industry structure. They argued that when a firm is operating in a multi-domestic industry, it is difficult for the acquiring firm to benefit from product standardization, and the local knowledge of local top managers supporting capabilities' transfer and organizational learning is important for value creation and so such local managers are retained. In contrast, in global industries, product standardization means that geographically diverse firm locations become part of a firm's global network in which local market knowledge is less critical and so the turnover rate of local top managers is likely to be higher.

A recent meta-analytic review on turnover and post-acquisition performance emphasized a strong consideration of psychological variables by stating that "future research should examine whether this strong negative influence of $\mathrm{TMT}^{2}$ turnover on postacquisition performance can be explained by the behavioral and emotional reactions of acquired firm employees to the loss of their firms' management team ..." (Bilgili, Calderon, Allen, \& Kedia, 2017, p. 1990). Similarly, Krug et al. (2014) in a review of turnover following an acquisition highlight that, in sum, psychological

\footnotetext{
${ }^{2}$ Top management team
}

Rights statement: This is the authors' version of the article that has been accepted for publication in Human Resource Management Review and undergone full peer review but has not been through the copyediting, typesetting, pagination and proofreading process, which may lead to differences between this version and the Version of Record. 
attributes and perceptions have a great impact on employees/executives' decision to stay or leave. Thus, our extant review of findings on turnover in M\&A so far indicates that this important and extensive literature, which examines determinants such as the nature of the $M \& A$, firm characteristics and industry characteristics, has undoubtedly produced inconsistent, mixed and often contradictory results. Hence, it demonstrates the need to also examine the psychological attributes and perceptions of the acquisition.

In the same vein, prior studies show that autonomy granted to the acquired firm employees/executives as well as its removal can greatly influence employees to stay or leave following an M\&A (Ahammad et al., 2012; Hagedoorn \& Hesen, 2007; Hambrick \& Cannella, 1993; Very et al., 1997), although the findings are mixed and inconsistent. The notion of 'autonomy' has been found to be of great importance to acquired employees/top executives during post-merger integration (PMI) (Baytos, 1986; Bradley \& Korn, 1981; Buono \& Bowditch, 1989, 2003). According to Datta and Grant (1990) autonomy simply refers to the discretion over the acquired firm's operating decisions given to the acquired firm's employees/executives, whereas Hambrick and Cannella (1993) describe the loss of autonomy as the degree to which the strategy, systems and procedures associated with the management of the acquired company are removed from their discretion. In fact, loss of autonomy or having autonomy represents a crucial component of HR issues relating to the PMI phase - as this phase is regarded to be potentially crucial to M\&A success (Angwin \& Meadows, 2015; Bauer \& Matzler 2014).

Rights statement: This is the authors' version of the article that has been accepted for publication in Human Resource Management Review and undergone full peer review but has not been through the copyediting, typesetting, pagination and proofreading process, which may lead to differences between this version and the Version of Record. 
While the PMI phase is often characterized by a sense of a lack of control (Weber \& Tarba, 2010), a loss of autonomy is also often felt, especially among the acquired firm's employees. For example, following an M\&A, the management of the acquired firm is often under considerable pressure to conform to the buyer's management practices (Schweiger \& Weber, 1989), in the realms of strategic planning, financial reporting and also seeking approval from the buying firm in areas such as budgeting and negotiations, where they previously held full autonomy (Haspeslagh \& Jemison, 1991). As a result of the new pressures and challenges faced in the PMI phase, management of the acquired firm increasingly can feel inferior or controlled by the management of the buying firm. In such a situation, employee retention and psychological ownership can become problematic in the acquired firm. For example, Hambrick and Cannella (1993) studied the concepts of relative status and autonomy removal and concluded that top managers were less likely to leave when they were given increased status and autonomy within the newly formed organization. They added that "some acquisitions result in extremely low relative standing for acquired executives - they feel inferior, the acquirers see them as inferior and themselves as superior, autonomy is removed, status is removed and a climate of acrimony prevails" (Hambrick \& Cannella, 1993, p.733). The above-mentioned authors' work essentially identified loss of autonomy as a core feature of relative standing and thus implied that maintaining the relative standing of the acquired firm employees/executives will improve the retention of the acquired firm employees/executives (Schweiger \& Goulet, 2000). The implication of the last sentence is that the loss of autonomy can also have a

Rights statement: This is the authors' version of the article that has been accepted for publication in Human Resource Management Review and undergone full peer review but has not been through the copyediting, typesetting, pagination and proofreading process, which may lead to differences between this version and the Version of Record. 
strong moderating effect on acquired firm employees' retention. Similarly to the effect of relative standing on acquired employee/executive retention, the promotion of acquired employees/executives to the management team of the newly merged firm may aid in providing them a positive sense of worth in the post-M\&A organization (Ranft \& Lord, 2000), and thus help enhance employee retention. Additionally, a study of acquired European firms by Very and his colleagues found that the loss of autonomy by individuals accustomed to high levels of autonomy led to performance deterioration (Very et al., 1997). Moreover, other scholars find that loss of autonomy creates a sense of loss and failure in acquired firms (Bleeke \& Daniels, 1985; Siehl, Smith, \& Omura, 1990). The above findings point to the fact that a greater degree of autonomy does yield a positive effect on employee retention within an acquired firm, as it increases the relative decision-making opportunity of acquired firm employees and facilitates their ability to maintain greater control over their environments (cf. Ahammad et al., 2012; Hambrick \& Cannella, 1993; Very et al., 1997). In fact, being able to maintain a greater control over one's surroundings may particularly be salient in the case of knowledgeintensive M\&As (aimed at acquiring new knowledge, skills and capabilities), where highly skilled professionals or knowledge workers, such as engineers and scientists tend to desire/require relatively high degrees of autonomy (e.g. Degbey, 2016a, 2016b; Puranam, Singh \& Zollo, 2006; Paruchuri, Nerkar, \& Hambrick, 2006).

Contrary to the above evidence and suggestions, Krug et al. (2014) argue that the effect of acquired entities' autonomy (or its removal) on turnover may depend on executive seniority, such that the replacement of a senior executive may send positive

Rights statement: This is the authors' version of the article that has been accepted for publication in Human Resource Management Review and undergone full peer review but has not been through the copyediting, typesetting, pagination and proofreading process, which may lead to differences between this version and the Version of Record. 
signals to acquired employees that they are in charge, and therefore, enhance their retention. From the acquired firm's point of view, senior executives are more accustomed to exercising autonomy than other employees or less senior executives, and thus the loss of such autonomy following the M\&A may attract more negative responses and trigger speedy departure among them (Krug et al. 2014). Additionally, Paruchuri et al., (2006) studied the relationship between acquisition integration and productivity losses among acquired inventors using a sample of 3,933 inventors in pharmaceutical firms whose companies were acquired, and found that the productivity of corporate scientists of acquired firms was generally impaired by integration (i.e., a form of autonomy removal), but the integration had varying productivity effects on inventors/scientists depending on the disruption of their prior substantive and social contexts. For example, as their findings showed, integration caused the most severe productivity drops among inventors/scientists who had lost the most social status and centrality in the newly merged organization (Paruchuri et al., 2006). In addition, applying both the theory of relative standing and the financial incentive mechanism of retention on a sample of cross-border acquisitions made by UK firms to investigate the roles of financial incentives, acquirer's commitment and autonomy in top management retention, Ahammad et al., (2012) find contrary to conventional knowledge, that when financial incentive interacts with other variables such as autonomy for acquired employees, it may have a negative impact on retention-indicating that socially oriented issues associated with autonomy may be more relevant determinants of top management team retention than economic incentives, in certain circumstances. This

Rights statement: This is the authors' version of the article that has been accepted for publication in Human Resource Management Review and undergone full peer review but has not been through the copyediting, typesetting, pagination and proofreading process, which may lead to differences between this version and the Version of Record. 
finding seems consistent with the contention of Ranft and Lord (2000, p.315) who suggest that "the broader social logic behind the theory of relative standing therefore appears to be a better predictor of employee retention than a theory simply based on direct, personal economic interests". Moreover, Lubatkin et al., (1999) also found that predicting the cause or management of turnover was determined by culture clash between the top management teams in the M\&A and autonomy removal from acquired managers. Furthermore, whilst most findings regard autonomy for the acquired firm employees as a good thing, there is still a lingering, persistent dilemma when high levels of autonomy are granted to acquired firms. A high level of autonomy (i.e. low level of integration of both firms) may lead to a low successful transfer, sharing and combination of resource and capability (e.g. Aklamanu, Degbey, \& Tarba, 2016; Ranft, 2006). This implies that expected synergies to be realized through integration could be severely challenged in favor of, for example, retaining employees. We contend that although findings regarding the loss of acquired firm autonomy are mixed, confusing and contradictory, they certainly offer us the possibility to carefully observe evidence from various studies in order to also establish its linkage with psychological mechanisms of M\&As and employee retention (see, Figure 1).

A collective insight obtained from prior works discussed above on turnover/retention as well as on autonomy removal from the acquired firm indicate that M\&As do cause loss of psychological ownership to acquired firm employees. Krug et al. (2014, p. 158) for example state that, "in short, patterns of executive turnover are likely to vary based on the objectives of the acquisition and the psychological attributes

Rights statement: This is the authors' version of the article that has been accepted for publication in Human Resource Management Review and undergone full peer review but has not been through the copyediting, typesetting, pagination and proofreading process, which may lead to differences between this version and the Version of Record. 
and personal motivations of executives who negotiate the deal". And concluded in their review article that "existing research has yet to capture ... the complex link between executive turnover and post-acquisition performance using alternative theoretical explanations" (Krug et al., 2014, p. 160). Our article seeks to offer a psychological ownership perspective as an important alternative theoretical explanation to advance understanding in this area.

\subsection{Employees' psychological ownership}

Etzioni (1991) argued that ownership is a dual creation; one is a psychological attitude (i.e., a psychological attitude which exists in one's mind), and the other is an objective entity (i.e., an objective entity which exists in reality). In this respect, Pierce, O'Driscoll and Coghlan (2004) argued that important distinctions exist between legal and psychological ownership, in spite of the fact that the two are somewhat related. Legal ownership/possession is recognized by society, and therefore the rights that accompany ownership are specified and protected by a legal system. In contrast, psychological ownership is experienced foremost by the individual who holds this feeling, and thus the one who manifests the felt rights associated with psychological ownership. 'Possessiveness' underlies the conceptual core of psychological ownership, although it represents not only feelings of possession (Pierce et al., 1991, 2001), but also the concern for and felt responsibility for a particular target, such as an organization (O’Reilly, 2002; Parker et al., 1997). In this article, the work of Pierce et al. (2001) sets the stage for defining the concept of psychological ownership by

Rights statement: This is the authors' version of the article that has been accepted for publication in Human Resource Management Review and undergone full peer review but has not been through the copyediting, typesetting, pagination and proofreading process, which may lead to differences between this version and the Version of Record. 
concluding that (i) the "feelings of possession or feelings of ownership" ${ }^{3}$ are inherently human, (ii) feelings of ownership can ensue toward both material and immaterial objects, (iii) feelings of ownership have significant emotional, attitudinal and behavioral effects on those that experience ownership. The following three main variables (i.e. controlling the target, coming to intimately know the target and investing the self into the target) have been identified as the routes/mechanisms through which the concept of psychological ownership emerges/develops (see Pierce et al., 2001 for review). Within organization and management research, psychological ownership is a recent organizational behavioral concept (Pierce et al., 2001; 2003; Van Dyne \& Pierce, 2004). As such, much of the work on psychological ownership is based on conceptual research with limited empirical studies in organizations (e.g. Avey et al., 2009; Pierce et al., 2004; Van Dyne \& Pierce, 2004). Thus, more conceptual examples of employees' psychological ownership in organizations exist to date than empirical ones.

The limited studies which examine employees' feeling of ownership for their jobs and organizations cut across many industries including manufacturing, services, hospitality and media in diverse countries such as the United States, Australia, China, Singapore and New Zealand (Van Dyne \& Pierce, 2004; Vandewalle et al., 1995; Avey et al., 2009; Brown et al., 2005; Brown et al., 2014; Bernhard \& O’Driscoll, 2011). For example, Van Dyne and Pierce (2004) investigated employees' feelings of ownership for the organization and workers' attitudes and behaviors in three different samples

\footnotetext{
${ }^{3}$ Supportive of the work of prior scholars, the terms "feelings of possession" and "feelings of ownership" (e.g. Dittmar, 1992; Furby, 1978; Pierce et al. 2001) are used interchangeably in this study.
}

Rights statement: This is the authors' version of the article that has been accepted for publication in Human Resource Management Review and undergone full peer review but has not been through the copyediting, typesetting, pagination and proofreading process, which may lead to differences between this version and the Version of Record. 
drawn from multiple industries and multiple organizations in the United States. Nearly 800 employees, managers and peers responded to questionnaires on the links between psychological ownership for their organizations and a number of work attitudes (e.g. organizational commitment, job satisfaction, organization-based self-esteem). Data was also collected on the impact of psychological ownership on employees' work behaviors (e.g. performance and organizational citizenship behaviors). The authors found significant positive relationships between psychological ownership and employees' attitudes and behaviors in all three field samples. Specifically, employees who had high feelings of ownership for their organizations also reported high degrees of commitment to their organizations, satisfaction to their jobs and a positive self-image of themselves in their various organizations. Similarly, there were strong relationships between employees' feelings of ownership for their organizations and their organizational citizenship behaviors. Employees with a high degree of psychological ownership were more likely to engage in discretionary work behaviors that were not part of their formal job descriptions, nonetheless, only a low correlation was found between psychological ownership and employees' work performance.

Similarly, Vandewalle et al., (1995) studied the impact of psychological ownership on employees' work behaviors (e.g. extra-role behaviors) and attitudes (e.g. satisfaction, organizational commitment) in a large University housing cooperative. The authors found that psychological ownership was positively related to extra-role behaviors and this relationship was mediated by employees' commitment to their organization. In addition, relative to other organizational variables (e.g. satisfaction),

Rights statement: This is the authors' version of the article that has been accepted for publication in Human Resource Management Review and undergone full peer review but has not been through the copyediting, typesetting, pagination and proofreading process, which may lead to differences between this version and the Version of Record. 
the authors found that psychological ownership predicted extra-role behaviors better than satisfaction for one's job. In line with the researchers' expectations, residents of the housing cooperatives reported higher levels of in-role behaviors than extra-role behaviors. Thus, the authors concluded that psychological ownership had a stronger relationship with extra-role behaviors than in-role behaviors. Moreover, in another study examining an expanded view of psychological ownership among 316 members of a Mid-Western University in the United States, Avey et al., (2009) found that psychological ownership had two main components - a promotion-focused aspect comprising of self-efficacy, accountability, sense of belongingness and self-identity; and a second component of psychological ownership was what the researchers called prevention-focused which included the concept of territoriality (Brown et al., 2005). Examination of the two components of psychological ownership (promotion and prevention-focused) with other organizational related concepts (e.g. organizational citizenship behaviors, transformational leadership, satisfaction, workplace deviance, intentions to stay with an organization) provided further insights into the nature of psychological ownership and its relationships with organizational concepts. For instance, the authors found that in contrast to the promotion-focused form of psychological ownership, the prevention-focused aspects of psychological ownership (i.e. territoriality) had no significant relationship with transformational leadership or other outcome variables such as affective commitment, job satisfaction or organizational citizenship behaviors (Avey et al., 2009). Conversely, promotionfocused psychological ownership with the dimensions of self-efficacy, accountability,

Rights statement: This is the authors' version of the article that has been accepted for publication in Human Resource Management Review and undergone full peer review but has not been through the copyediting, typesetting, pagination and proofreading process, which may lead to differences between this version and the Version of Record. 
belongingness and self-identity showed a positive relationship with transformational leadership, organizational citizenship behaviors, affective commitment to the organization, job satisfaction and intentions to stay with the organization. However, workplace deviance was negatively related to psychological ownership.

Bernhard and O'Driscoll (2011) also studied the role of employees' psychological ownership on various styles of leadership and employees' attitudes and behaviors in family-owned businesses. Nearly 229 employees responded to surveys on their psychological ownership for the family business and psychological ownership for their jobs. Employees also reported on the leadership styles of their managers (i.e. transformational, transactional and laisser-faire) as well as employees' attitudes (i.e. organizational commitment, job satisfaction) and behaviors (i.e. in-role and extra-role behaviors, turnover intentions). The researchers found that certain leadership styles (e.g. transformational and transactional) were better facilitators of employees' psychological ownership for the family business and employees' jobs than the passive leadership style of laisser-faire. Of particular interest in this study was the finding that employees' psychological ownership for their organizations and their jobs strongly influences the relationships between leadership styles and employees' affective commitment, job satisfaction and turnover intentions. Psychological ownership also mediated the relationship between transformational leadership style and employees' organizational citizenship behaviors. Further evidence from two separate studies confirmed the mediating role of psychological ownership between work environment structures (e.g. job complexity) and employees' performance. For example, Brown et

Rights statement: This is the authors' version of the article that has been accepted for publication in copyediting, typesetting, pagination and proofreading process, which may lead to differences between this version and the Version of Record. 
al., (2014) found significant positive relationships between job complexity and psychological ownership for one's jobs. Furthermore, psychological ownership mediated the relationship between job complexity and performance among 424 salespeople in a large U.S. based Consumer Goods Company. This finding was replicated in a second study in which the routes of psychological ownership (i.e. intimate knowing, investment of self and controlling objects) mediated relationships between job complexity and psychological ownership for one's jobs. Thus, providing greater insights into how employees develop psychological ownership for objects (e.g. jobs, workspace) in organizations.

Also, in a study investigating the mediating role of organizational commitment in Taiwanese high-tech organizations focusing on the effect of employee participation in decision making (PDM) on employees' psychological ownership which in turn can lead to their knowledge-sharing behavior, Han et al. (2010) found that both commitment and employee participation in decision-making (also described as employee involvemente.g. Brown \& Cregan, 2008) were positively related to psychological ownership. Thus, since psychological ownership is committed by employees who sense this feeling and comparative privileges recognized by them, they are more likely to develop positive attitudes and stronger employee commitment. Additionally, the exploratory study of Long (1978) showed that, although ownership directly influenced commitment, it also indirectly increased commitment through increasing employee involvement. This implies that an increase in employee involvement may have a positive effect on employee commitment.

Rights statement: This is the authors' version of the article that has been accepted for publication in Human Resource Management Review and undergone full peer review but has not been through the copyediting, typesetting, pagination and proofreading process, which may lead to differences between this version and the Version of Record. 
Following the above examples, it is clear that feelings of ownership are indeed a real phenomenon that employees and executives easily experience, recognize and appraise with respect to their work and organizational context (cf. Pierce et al., 2004). We contend that providing these explicit elaborations of behavioral issues of the concept has certainly helped in making better sense of ownership with respect to the other variables in our theorized relationships outlined in Figure 1. Based on the discussions in this and earlier sections, we can argue that the loss of psychological ownership will cause less commitment and involvement in M\&A. In addition, the lower commitment and involvement in M\&A will cause employee turnover (or reduction in retention). Moreover, loss of acquired firm autonomy is related to ownership and turnover, and therefore a loss of autonomy will moderate the relationships between ownership and the two mediating variables (i.e., commitment and involvement) as well as between the mediating variables and turnover/retention. The next section provides further elaborations of the conceptual development with testable propositions.

\section{Development of testable propositions}

\subsection{Psychological ownership and employee retention: Direct and}

\section{mediating effects of employee commitment}

Commitment as a concept has received a great deal of attention as an antecedent (e.g. to predict employees' turnover), correlate (e.g. employee involvement) and outcome (e.g. output measures) of other work-related variables of interest in both empirical and conceptual studies (e.g. Hassett 2012; Klendauer \& Deller, 2009;

Rights statement: This is the authors' version of the article that has been accepted for publication in Human Resource Management Review and undergone full peer review but has not been through the copyediting, typesetting, pagination and proofreading process, which may lead to differences between this version and the Version of Record. 
Mathieu \& Zajac, 1990; Meyer \& Allen, 1991). One of the most commonly adopted definitions of the concept from an organizational perspective, which we follow in this paper is that of Mowday et al. (1982). They defined commitment (i.e. attitudinal aspect) as the relative strength of an individual's identification with and involvement in a particular organization. Findings of several studies examining the relationships between employee commitment particularly affective commitment to the organization and psychological ownership suggest that psychological ownership has a significant and positive relationship with affective commitment to the organization (Van Dyne \& Pierce, 2004; Pierce et al., 1991; Vandewalle et al., 1995). For instance, Van Dyne and Pierce (2004) found significant positive relationships between psychological ownership and affective commitment to the organization. Furthermore, the authors found that after accounting for demographic variables such as age, educational level, gender and tenure, psychological ownership predicted a quarter of the variances explained in commitment to the organization. In another study, O'Driscoll et al. (2006) observed that psychological ownership for the job and the organization were associated with the levels of work environment structure (e.g. autonomy, participative decision making) and several employees' work-related behaviors including organizational commitment. In their study, O'Driscoll et al. (2006) found that employees who work in environments that permit higher autonomy and participative decision-making will exercise more personal control, have greater knowledge about their jobs and organizations and are more likely to invest themselves extensively into the work they perform. Furthermore, employees are likely to engage in organizational citizenship behaviors and have high

Rights statement: This is the authors' version of the article that has been accepted for publication in Human Resource Management Review and undergone full peer review but has not been through the copyediting, typesetting, pagination and proofreading process, which may lead to differences between this version and the Version of Record. 
levels of commitment to their organization (Pierce et al., 2004). The significant relationships between psychological ownership and organizational commitment have been corroborated in several research studies (Mayhew et al., 2007; Vandewalle et al., 1995; Brown et al., 2005). The study of Han et al. (2010) showed that employees who perceive a feeling of ownership of the organization view themselves as relevant organizational members and thus commit to the organization.

Within the context of M\&A specifically, several studies have established connection between organizational commitment and employee turnover/retention (e.g. Ahammad et al., 2012; Hassett 2012; Cartwright et al., 2007; Amiot et al., 2007), except for this connection with employees' psychological ownership. However, recent studies have gradually started paying attention to underlying psychological phenomena that might explain M\&A outcomes (e.g. Reus, 2015; Kusstatscher \& Cooper, 2005; Sinkovics et al., 2011). There remains a clear need to focus more attention on how psychological and human resource issues impact upon M\&As, considering the persistent mixed and contradictory results of M\&A provided essentially by the 'rational track' literatures from financial economics and strategic management. Evolving focus on the 'human' side of M\&As underlines the key importance of employee involvement, participation and commitment to the M\&A process. Bartels et al. (2006) argue this point by demonstrating that employee involvement generates better identification with the organization (e.g. Edwards, 2005), which subsequently leads to improved employee commitment to the new organization following M\&A. If employees can identify and develop a strong bond with the newly formed organization, they are more likely to stay

Rights statement: This is the authors' version of the article that has been accepted for publication in copyediting, typesetting, pagination and proofreading process, which may lead to differences between this version and the Version of Record. 
as well as experience less negative health effects following an M\&A event. The important point to recognize here is that following a merger or an acquisition, previous organizational identities and concomitant organizational commitment to the previous firm require reshaping toward the new organizational entity. To this end, Colman and Lunnan (2011) highlighted how the extent of identification and commitment to a newly merged organization was dependent upon how this organization was viewed by employees - as being of high status, leading to positive social identity or being of low status, leading to negative social identity. Related to this point, Amiot et al., (2007) argue that high status groups adjust to new organizational systems and processes quicker and are more productive than low status groups where over time commitment to the newly merged organization decreases. However, there still remains the real possibility that high status groups, if they feel threatened following a merger can engage in resistance to the process of PMI (Ullrich et al., 2005; Van Knippenberg et al., 2002). Further, in a longitudinal case study on acquired key employees, Raukko (2009) found commitment to be crucial for employees' retention/turnover, and showed that key employees' organizational commitment was closely linked to how they perceived and experienced the PMI phase, as well as their prior role in the acquired company. Furthermore, Kusstatscher and Cooper (2005), emphasized the importance of managing emotions in M\&A to enhance employee commitment during the PMI phase, and consequently improve for example, employee retention following the M\&A. Overall, empirical findings and in-depth conceptual arguments suggest that underlying psychological phenomena do have strong positive relationship with employee

Rights statement: This is the authors' version of the article that has been accepted for publication in Human Resource Management Review and undergone full peer review but has not been through the copyediting, typesetting, pagination and proofreading process, which may lead to differences between this version and the Version of Record. 
commitment. In this article, for example, our review of prior studies demonstrates that psychological ownership has a strong positive relationship with employee affective organizational commitment but the relationship between psychological ownership and other forms of commitment - continuance commitment and normative commitment have been inconclusive with some studies reporting low to insignificant results (Mayhew et al., 2007; Brown et al., 2005). Based on the preceding discussion, we propose the following:

Proposition 1: Acquired firm employee psychological ownership is positively related to employee commitment in M\&A (or a loss of employee psychological ownership will cause lower employee commitment in M\&A).

\subsection{Psychological ownership and employee retention: direct and}

\section{mediating effects of employee involvement}

Employee involvement refers to the existence within the work milieu where employees have the possibility to impact upon decisions and actions that affect their jobs and the operating of the firm/organization (Jimmieson \& White, 2011). Similarly, Long (1978) defined involvement within the organizational setting, as a feeling of solidarity with the organization, a feeling of membership or belongingness. Within the HRM and organizational change literature, employee involvement is found to correlate significantly with positive employee behaviors and wider feelings of employee wellbeing (see Brown \& Cregan, 2008; Guest 2002; Marks \& Mirvis, 2011; Petrescu \& Simmons, 2008; Van Dick et al., 2006). For example, in the general HRM literature, it is argued that employees' involvement in decision-making facilitates the creativity

Rights statement: This is the authors' version of the article that has been accepted for publication in Human Resource Management Review and undergone full peer review but has not been through the copyediting, typesetting, pagination and proofreading process, which may lead to differences between this version and the Version of Record. 
and reaching of organizational goals (Marks \& Mirvis, 2011). Similarly, in addition to providing positive solutions to organizational challenges, evidence suggests that employee involvement practices can have positive effects on job satisfaction and support of proposed changes within an organization (Brown \& Cregan, 2008), with such influence on employees who feel valued within an organization less likely desiring to leave (Van Dick et al., 2006). Moreover, greater employee involvement can generate increased trust in an organization (Petrescu \& Simmons, 2008) and integration and organizational alignment (Waldman \& Javidan, 2009).

Within the M\&A context — which is essentially also an organizational change context - it is argued that employee involvement plays a key role in the successful implementation of the M\&A, allowing employees to feel empowered, giving them feelings of control and thus having a positive effect on employees' behavior (Vasilaki et al., 2016). In particular, research has demonstrated that it is especially important to retain key talents of the acquired firm, and one approach to do this is to involve them at an early stage in the M\&A process (Krug \& Nigh, 1998; Schuler et al., 2004). Bartels et al., (2006) argue that employee involvement allows greater identification with the firm and aids the commitment of employees during the post-acquisition stage. Similarly, Patchen (1970) suggested that commitment may occur as a result of involvement (i.e. feelings of solidarity and membership), indicating that a close relationship exists between employee commitment and involvement (see also illustration in Figure 1).

Rights statement: This is the authors' version of the article that has been accepted for publication in Human Resource Management Review and undergone full peer review but has not been through the copyediting, typesetting, pagination and proofreading process, which may lead to differences between this version and the Version of Record. 
Moreover, based on a qualitative, large-scale study of eight acquisitions conducted by Finnish multinationals, Teerikangas (2012) finds that in contrast to most M\&A research portraying employee reactions during the M\&A process in a negative light, more positive responses were found. In six out of the eight acquisitions, employees' reactions were of motivation rather than uncertainty, seeing the acquisitions as opportunities rather than threats. The study found that the degree of acquired firm managerial involvement in the pre-deal stage had the strongest predictor effect on employee reactions. Indeed, when an M\&A was perceived as an opportunity rather than as a threat, this resulted in acquired firm managers proactively striving to make the acquisition happen. Therefore, there may be a clear incentive for acquiring firm managers to ensure that their counterparts in the acquired firm have an active involvement and interest toward the acquisition.

As Figure 1 shows, the linkage between psychological ownership and involvement is of critical importance. It is noted earlier in this study that psychological ownership is a relatively new organizational behavioral concept (Pierce et al., 2001; 2003) and little research exists specifically examining links between psychological ownership and employee involvement (Lawler \& Hall., 1970). However, earlier insights above and, empirical evidence from employees' stock ownership (Buchko, 1993; French \& Rosenstein., 1984) provide some insights into potential relationships between psychological ownership and employee involvement. For instance, there is a positive relationship between employees' sense of loyalty to their organization and employees' participation in stock ownership schemes (Buchko, 1993). Employees who hold shares

Rights statement: This is the authors' version of the article that has been accepted for publication in Human Resource Management Review and undergone full peer review but has not been through the copyediting, typesetting, pagination and proofreading process, which may lead to differences between this version and the Version of Record. 
in their ownership are more likely to identify with their organizations and have a sense of control or formal authority in their work (French \& Rosenstein, 1984). Thus, evidence from employees' stock ownership may provide insights for proposing relationships between psychological ownership and involvement because there are ample studies that have shown that psychological ownership relates positively to several employees' attitudes and behaviors (see Pierce et al., 2001; 2003 for review) including job satisfaction, organizational commitment, performance and organizational citizenship behaviors (Van Dyne \& Pierce, 2004; Mayhew et al., 2007; Brown et al., 2014). Furthermore, the review work of Cotton et al. (1988) found that employee ownership is a form of participation in decision-making (PDM) and that this form of PDM has a 100\% positive association with performance. Cotton et al. (1988) also noted that employees' involvement in organization (decisions) is an important outcome for evaluating PDM. Therefore, a loss in employee ownership can cause a loss in (or lower) employee involvement, ceteris paribus. Based on the preceding discussion, we propose the following:

Proposition 2: Acquired firm employee psychological ownership is positively related to employee involvement in M\&A (or a loss of employee psychological ownership will cause lower employee involvement in M\&A).

Additionally, based on the discussions and propositions presented above on the theorized relationships between employee psychological ownership, and employee commitment and involvement (see P1 and P2 in Figure 1), we argue that there exists a positive linkage between employee commitment and involvement, and employee

Rights statement: This is the authors' version of the article that has been accepted for publication in Human Resource Management Review and undergone full peer review but has not been through the copyediting, typesetting, pagination and proofreading process, which may lead to differences between this version and the Version of Record. 
retention (e.g. Bartels et al., 2006; Krug \& Nigh, 1998; Raukko, 2009; Schuler et al., 2004). This also means that a decrease in employee commitment and involvement in the M\&A process will cause employee turnover. Furthermore, we draw on expectation theory (e.g. Steel \& Konig, 2006; Vroom, 1964) to further justify the direct and mediating effects of both employee commitment and involvement in the last stated argument (above), and as indicated in the theorized relationships in our moderated mediation model (see Figure 1). It argues that the value of a first-level outcome (i.e., commitment and involvement) is a function of the instrumentality of that behavior (i.e., feeling of ownership) for the actor (i.e., acquired employee) and the value of the secondlevel outcome (i.e. acquired firm's employee retention) associated with that behavior. Specifically in our model, the mediation variables of employee commitment and involvement in M\&A are first-level outcomes with high value of psychological ownership for acquired firm's employee. Acquired firm's employee retention is a second-level outcome associated with commitment and involvement that has high value itself, as it constitutes the main goal of psychological ownership for an acquired firm's employee. In sum, our theorizing postulates that both employee commitment and involvement mediate the relationship between an acquired firm's employee psychological ownership and retention (see Baron \& Kenny, 1986; Preacher \& Hayes, 2008). As a result, we propose the following:

Proposition 3a. Employee commitment in M\&A is positively related to acquired firm's employee retention (or lower employee commitment in M\&A will cause acquired firm's employee turnover).

Rights statement: This is the authors' version of the article that has been accepted for publication in Human Resource Management Review and undergone full peer review but has not been through the copyediting, typesetting, pagination and proofreading process, which may lead to differences between this version and the Version of Record. 
Proposition 3b. Employee involvement in M\&A is positively related to acquired firm's employee retention (or lower employee involvement in M\&A will cause acquired firm's employee turnover).

Proposition 4a. Employee commitment in M\&A mediates the relationship between acquired firm's employee psychological ownership and retention.

Proposition 4b. Employee involvement in M\&A mediates the relationship between acquired firm's employee psychological ownership and retention.

\subsection{Psychological ownership, commitment, involvement and turnover: The moderating effect of loss of autonomy}

The works of Avey et al. (2009) and Bernhard and O’Driscoll (2011) suggest that turnover is negatively related to psychological ownership. That is, individuals with low levels of feeling of ownership for their jobs and organizations are more likely to feel less commitment to their organizations and are less likely to stay with their organizations (Avey et al., 2009). In a study of 52 family-owned businesses, Bernhard and O'Driscoll (2011) found that employees' psychological ownership for their jobs and the organization had a significant influence on the styles of leadership adopted by managers (i.e. transformational, transactional and laisser-faire) and employees' affective commitment to their organizations and their intentions to stay with their organization. That is, psychological ownership is a significant mechanism through which leaders might exert influence on employees' attitudes and work behaviors (Bernhard \& O’Driscoll, 2011; Van Dyne \& Pierce, 2004). The results of several studies have found positive relationships between psychological ownership and

Rights statement: This is the authors' version of the article that has been accepted for publication in Human Resource Management Review and undergone full peer review but has not been through the copyediting, typesetting, pagination and proofreading process, which may lead to differences between this version and the Version of Record. 
autonomy (Hackman \& Oldham, 1975). In one study, Pierce, O’Driscoll and Coghlan (2004) examined relationships between employees' personal control over their jobs and work environments, the levels of autonomy employees had over their jobs and employees' psychological ownership for the job and organization. Working with an employee sample of 239 from 7 organizations in the service and manufacturing industries in New Zealand, the authors found positive and significant relationships between autonomy and the amount of control employees experienced in their work environments. In addition, employees who experienced more autonomy in their work were more likely to have high levels of psychological ownership for their jobs and organizations. Furthermore, perceived control mediated the positive relationships between employees' sense of autonomy over their work and the feelings of ownership for their jobs and organizations. Thus, the authors concluded that the extent to which employees experienced control over their work environments is positively related to their feelings of ownership for their jobs and organizations (Pierce et al., 2004). Similarly, in another study investigating both employees' psychological ownership for their jobs and organizations and their levels of autonomy for their work, Mayhew et al., (2007) found positive relationships between psychological ownership for the organizations and jobs and employees' levels of autonomy for their jobs. The findings of this study are consistent with evidence from previous studies that workers who experienced higher levels of autonomy in their jobs are more likely to have greater control over their work environments and are more likely to feel ownership for their jobs and organizations (Pierce et al., 2004). In our proposed model (see Figure 1), it

Rights statement: This is the authors' version of the article that has been accepted for publication in copyediting, typesetting, pagination and proofreading process, which may lead to differences between this version and the Version of Record. 
can be observed that loss of acquired firm autonomy has a moderating effect on the relationship between employees' psychological ownership and employees' commitment and involvement, and, ultimately, on employees' retention.

Under major or extensive circumstances of change such as during an M\&A, employees will most likely draw information from events occurring at all levels. This may imply that selected acquired employees, such as HR integration managers, from whom other lower or same level employees may look to for guidance cannot cease from being a meaningful source of feedback, irrespective of the fact that they (i.e., HR integration managers) may still be wrestling themselves to fully comprehend the implications of the change (e.g. Greller, 2004). Acting as a leader and/or a repository of HR related matters, the autonomy granted to employees particularly among the acquired firm ones will enhance their retention. For example, the literature on knowledge intensive or technology-based acquisitions indicates that human resources and key employees often represent the most critical resource in the (acquired) organization, and thus greater emphasis on human resource integration should be amplified in such transactions (e.g. Birkinshaw, 1999). This is based on the fact that M\&As lead to higher than usual turnover rates among employees and top management teams particularly in the acquired firm (Cannella \& Hambrick, 1993; Krug \& Hegarty, 2001), and this rate of turnover according to Krug (2003) can even last for nearly nine years following the M\&A.

Therefore, the loss of acquired firm autonomy does influence the outcome of retention (or turnover), as it moderates employees' feeling of ownership, for example,

Rights statement: This is the authors' version of the article that has been accepted for publication in Human Resource Management Review and undergone full peer review but has not been through the copyediting, typesetting, pagination and proofreading process, which may lead to differences between this version and the Version of Record. 
through their control of the object of ownership, intimate knowledge of the object of ownership and the self-investment of the individual in the object of ownership. That is to say, if the loss of autonomy does hinder acquired employees to adequately answer the question of "what do I feel is mine?" as a way of satisfying their motivation for selfefficacy/effectance, self-identity, belongingness (need for place), accountability and even territoriality, then their 'sense' of ownership to protect and improve the object of ownership will be weakened (cf. Avey et al., 2009; Pierce et al., 2001). Thus, the presence and level of autonomy granted to acquired firm employees that allows for employees' active imposition of self on the organization, through possibilities to exercise control over an organizational object (e.g. PMI job design), coming to intimately know the object and investing the self into the object, will lead to the emergence of feelings of ownership among them. For example, Pierce et al., (2001, p. 301) argue "jobs that provide greater autonomy imply higher levels of control and, thus, increase the likelihood that feelings of ownership toward the job will emerge".

With respect to the moderating effect of the theorized relationships presented in Figure 1, we expect that under a high level of loss of acquired firm's autonomy the relationship between employee psychological ownership and both employee commitment and involvement in M\&A is weaker than under low level of loss of acquired firm's autonomy. Therefore, the positive effect of acquired firm's employee psychological ownership on commitment and involvement should be stronger when the loss of autonomy is low compared to when it is high. Based on the preceding discussion, we propose the following:

Rights statement: This is the authors' version of the article that has been accepted for publication in Human Resource Management Review and undergone full peer review but has not been through the copyediting, typesetting, pagination and proofreading process, which may lead to differences between this version and the Version of Record. 
Proposition 5a. Loss of acquired firm's autonomy moderates the positive relationship between employee psychological ownership and commitment, such that the relationship is stronger when the level of autonomy lost is low compared to when it is high.

Proposition 5b. Loss of acquired firm's autonomy moderates the positive relationship between employee psychological ownership and involvement, such that the relationship is stronger when the level of autonomy lost is low compared to when it is high.

We further propose that loss of acquired firm's autonomy influences the strength of the theorized relationship between both employee commitment and involvement in M\&A and their retention, as formally stated below:

Proposition 6a. Loss of acquired firm's autonomy moderates the positive relationship between employee commitment in M\&A and employee retention, such that the relationship is weaker when the level of loss of autonomy is high compared to when it is low.

Proposition 6b. Loss of acquired firm's autonomy moderates the positive relationship between employee involvement in M\&A and employee retention, such that the relationship is weaker when the level of loss of autonomy is high compared to when it is low.

\section{Discussion and conclusions}

Rights statement: This is the authors' version of the article that has been accepted for publication in Human Resource Management Review and undergone full peer review but has not been through the copyediting, typesetting, pagination and proofreading process, which may lead to differences between this version and the Version of Record. 
The aim of this article is to develop a conceptual model that shows how employee retention can be enhanced through psychological mechanisms following an M\&A (Cartwright \& Cooper, 1993; Krug et al., 2014; Lee et al., 2013). In this article, we propose a psychological ownership perspective as an alternative to the predominant legal/formal ownership approach (e.g. employees' stock ownership, financial incentives) prevalent in M\&A, joint ventures and alliances literature. We argue that acquired firm employees' psychological ownership relates positively to acquired firm employees' retention through the intervening variables of commitment and involvement. We also propose that loss of acquired firm autonomy moderates the direct and indirect effects of psychological ownership on employees' retention via the mediating variables of commitment and involvement. To support our arguments, we began with an acknowledgement of employee psychological ownership as a critical attitudinal and behavioral barometer for improved employee retention, and emphasized to scholars and practitioners that M\&As are extreme cases of organizational change which often foreshadow higher turnover of employees.

Additionally, we observed that the HRM-stream of organizational behavior school in M\&A research may be under-represented, as it is essentially predicated on the legal/formal ownership system (e.g. legal transfer of equity possession, information, and influence/control from acquired to acquiring firm, employee stock ownership plans) for enacting critical organizational and HRM-related decisions for enhanced employee retention following M\&A. Moreover, we suggested that findings from previous studies showed that, when executives or managers discuss ownership, they

Rights statement: This is the authors' version of the article that has been accepted for publication in Human Resource Management Review and undergone full peer review but has not been through the copyediting, typesetting, pagination and proofreading process, which may lead to differences between this version and the Version of Record. 
typically intend to instill psychological ownership rather than financial ownership among employees, in order for them to have a feeling of responsibility to make decisions that are in the long-term interest of the organization (O'Reilly, 2002). Finally, our conceptual arguments are consistent with the findings of Ahammad et al., (2012) that financial incentives may actually have a negative effect on top management retention, contrary to our common knowledge, especially when this variable (i.e. financial incentives) interacts with other variables such as commitment and autonomy for the acquired firm. To conclude, we discuss theoretical implications, implications for practice and future research directions.

\subsection{Theoretical implications}

In this section, we discuss important theoretical contributions of our conceptual model to the M\&A, joint ventures and alliances literature. First, our main argument postulates that employee retention in M\&A is enhanced by the feeling of ownership that employees have for the organization (including their work), and not simply predicated on the formal ownership system, such as employees' stock ownership plan or the percentage of legal ownership stake in a firm. We believe this core argument contributes to the retention literature in particular and broader scholarly debates on what drives employees' retention/turnover in M\&A settings. Our conceptual model is distinct from previous employee retention studies in M\&A research (e.g. Ahammad et al., 2012; Krug \& Aguilera, 2005; Zhang et al., 2015) in that, it is underpinned by the conceptual core of employee 'possessiveness' (e.g. the feeling of possession is regarded as an integral part of employees' relationship with the organization-Kubzansky \&

Rights statement: This is the authors' version of the article that has been accepted for publication in Human Resource Management Review and undergone full peer review but has not been through the copyediting, typesetting, pagination and proofreading process, which may lead to differences between this version and the Version of Record. 
Druskat 1993, and strongly influencing employees' propensity to promote and resist change efforts—Dirks et al., 1996). Consistent with Staw (1991), employing a positive psychological concept, such as psychological ownership, can strengthen and provide solid theoretical substance to explaining phenomena such as employee retention following M\&A, by providing the underlying missing psychological process and/or mechanism.

Second, as a step toward developing a more elaborate understanding of the psychological ownership perspective and addressing the persistent problem that, onethird and one-half of all M\&A failures are attributable to people problems (e.g. Cartwright \& Cooper, 1993; Lee et al., 2013), this paper focuses its attention on employee retention, a relevant performance indicator in M\&A (e.g. Gomes et al., 2011; Krug \& Shill, 2008). We propose a conceptual moderated mediation model that explains the linkage between employees' psychological ownership and their retention following an M\&A. The proposed model highlights that employees' psychological ownership is positively related to employees' commitment and involvement, such that employees' loss of ownership causes lower employee commitment and involvement in M\&A. Moreover, high levels of employees' commitment and involvement in M\&A have a positive effect on employee retention (i.e. cause lower employee turnover). The effect of employees' psychological ownership on employees' commitment and involvement in M\&A is further moderated by loss of acquired firm autonomy (i.e. the positive relationship between employees' psychological ownership, and the mediating

Rights statement: This is the authors' version of the article that has been accepted for publication in Human Resource Management Review and undergone full peer review but has not been through the copyediting, typesetting, pagination and proofreading process, which may lead to differences between this version and the Version of Record. 
variables of commitment and involvement is weakened by loss of acquired firm autonomy).

Finally, the effect of commitment and involvement on retention is also moderated by loss of acquired firm autonomy (i.e. the positive relationship between commitment and involvement on retention is weakened by loss of acquired firm autonomy). We contribute to the extant M\&A, joint ventures and alliances literature by examining one psychological variable (i.e. psychological ownership) and the direct and indirect role psychological ownership plays in influencing employees' retention/turnover in M\&A settings. Our theoretical contributions build on previous studies that emphasized legal, financial and strategic explanations for employees' performance in M\&As (e.g. Krug \& Aguilera, 2005; Ahammad et al., 2012) by providing the 'psychological ownership' perspective for explaining employees' retention/turnover in M\&As.

\subsection{Implications for practice}

Psychological ownership research is still in its infancy (see Dawkins, Tian, Newman, \& Martin, 2017; Pierce et al., 2001; 2003 for review); thus, we are cautious but optimistic in drawing implications for practice. Nevertheless, we identified three implications for managers and executives in M\&A, joint ventures and alliances settings. First, for managers and executives involved in an M\&A, taking a psychological lens can provide novel insights into crucial strategic decisions, particularly with respect to strategic HRM-related issues in M\&A context, and also help to generate tangible, practical implications and awareness for managers and executives regarding the psychological elements behind employee retention (cf. Reus, 2015). Therefore,

Rights statement: This is the authors' version of the article that has been accepted for publication in Human Resource Management Review and undergone full peer review but has not been through the copyediting, typesetting, pagination and proofreading process, which may lead to differences between this version and the Version of Record. 
managers and executives are advised to be aware of employees' psychological tendencies, especially feelings of ownership behind the M\&A event. If employees' feelings of ownership are left unchecked, the effects can be costly for the overall performance of the firm. Second, our conceptual model highlights the need to consider intervening variables (e.g. mediators and moderators) in understanding effects of psychological ownership on employees' retention in M\&As. In particular, getting employees to commit and be involved in the M\&A process will amplify employees' feelings of ownership which in turn will lead to the acquired firm retaining their employees post-M\&As.

Finally, managers and executives can use our conceptual model as a guide to understand important psychological variables (e.g. psychological ownership, commitment, involvement, autonomy) in M\&A settings. Thus, managers and executives can develop appropriate training programs to foster employees' psychological ownership for the acquired firm. As we indicated in this article, employees can develop feelings of ownership for targets (e.g. jobs, organizations) if employees can control the target, know the target and invest in the target (Pierce et al., 2001). Managers and executives should provide opportunities for employees to have a sense of control, knowledge of and investment in the acquired firm. Consequently, training programs directed at the routes of psychological ownership (i.e. control, knowledge of and investment in the target) will help to increase employees' sense of psychological ownership for the acquired firm.

Rights statement: This is the authors' version of the article that has been accepted for publication in Human Resource Management Review and undergone full peer review but has not been through the copyediting, typesetting, pagination and proofreading process, which may lead to differences between this version and the Version of Record. 


\subsection{Future research directions}

This study, like most studies faces potential drawbacks that can provide suggestions for future research, few of which are discussed here. First, a key aim of this article was to develop a conceptual model that shows that psychological ownership for the acquired organization provides a clear-cut theoretical basis for understanding the inherent M\&A performance conundrum, particularly with respect to employee retention in M\&A. In particular, we proposed a moderated mediation model of psychological ownership on employee retention in M\&A, which is useful within its theoretical boundaries, and argue that the discussion of the proposed model and its identified variables are particularly salient to the M\&A context. Although the model links the M\&A performance variable (i.e. employees' retention) with psychological ownership, we believe the model is fairly parsimonious - using only five main variables including the dependent variable - it leaves out some potentially relevant organizational school M\&A success variables (e.g. cultural fit-Bauer \& Matzler, 2014; contextual ambidexterity—Meglio et al., 2015).

In addition, the inclusion of other M\&A success variables or more encompassing theoretical lenses from the process, financial economics and strategic management perspectives (e.g. Bauer \& Matzler, 2014; Gomes et al., 2013) may help to further develop the model and enhance its comprehensiveness. Further, a potential shortcoming of this article is that, we treated the term 'employees' as a unitary concept referring to both managerial and non-managerial employees of the acquired firms. Whilst this unitary perspective was useful in helping us to present our arguments

Rights statement: This is the authors' version of the article that has been accepted for publication in Human Resource Management Review and undergone full peer review but has not been through the copyediting, typesetting, pagination and proofreading process, which may lead to differences between this version and the Version of Record. 
without discussing hierarchical levels and structures of management, research has shown that employees and managers might perceive organizational change differently (Rooney, Paulsen, Callan, Brabant, Gallois, \& Jones, 2010). Thus, in future studies, researchers should consider investigating different levels of management (e.g. employees, middle managers, senior managers, executives) and their levels of psychological ownership for the acquired firm.

Furthermore, a second research direction concerns empirical analysis to test the propositions of our conceptual model. That is, research is needed to know whether the theoretical links between the formulated propositions can be established. The variables identified and discussed under psychological ownership may be evaluated empirically through employee surveys (e.g. Avey et al. 2009; Lee et al., 2013; Pierce et al., 2004; Van Dyne \& Pierce 2004). Also case studies can be used to investigate the phenomenon of psychological ownership as done in prior M\&A studies (e.g. Hajro, 2015; Rees \& Edwards, 2009; Swart \& Kinnie, 2003) as well as the use of interviews (e.g. Mäkelä \& Brewster, 2009) and narrative approaches (e.g. Xing, Liu, Tarba, \& Cooper, 2016). Future studies can also examine the interaction effect of the various routes/mechanisms of psychological ownership in this conceptual work to further help firms in executing their post-merger integration approaches and people management practices.

Also, future studies may build on the conceptual model developed in this paper by exploring the influence of other intervening variables (e.g. self-efficacy, self-identity, perceived behavioral control) and forms of HR employee management practices (e.g. recruitment and selection, reward management) in the M\&A context that may influence

Rights statement: This is the authors' version of the article that has been accepted for publication in copyediting, typesetting, pagination and proofreading process, which may lead to differences between this version and the Version of Record. 
individuals' sense of ownership for retention. A final research direction involves additional theorizing of psychological ownership in M\&A context. Although, our conceptual model is grounded in expectation theory (Steel \& Konig, 2006; Vroom, 1964), there are a plethora of organizational and management related theories that can be used to understand employees' psychological ownership in M\&A context. For example, Dawkins and colleagues (Dawkins et al., 2017) suggest social identity theory (Hogg \& Terry, 2000) or social exchange theory (Blau, 1964) as two plausible theoretical lens to understand employees' psychological ownership in organizational settings.

Before our concluding remarks, it is important to note that some scholars lamented that employees may regrettably be regarded as prostitutes; "trading their time for money, with no will, energy or passion for their work" (Avey et al., 2009 p. 187; see also Quinn, 1996). This lamentation perhaps signals what ownership might actually mean to employees, since it is expected that individuals will take care of, invest their time, energy and are also motivated to improve and protect objects they own. Hence, in conclusion, we delineated employee retention following M\&A to be determined by employees' psychological ownership for the organization, and thus offer a psychological ownership perspective to M\&A performance research. We developed a fairly parsimonious model for employees' psychological ownership that carefully explains the inherent performance challenge of M\&A in the form of acquired employees' retention by integrating extant theoretical and empirical literatures from HR-related M\&A studies and on organizational behavioral (or positive psychological)

Rights statement: This is the authors' version of the article that has been accepted for publication in Human Resource Management Review and undergone full peer review but has not been through the copyediting, typesetting, pagination and proofreading process, which may lead to differences between this version and the Version of Record. 
concepts. We discussed employee retention in terms of the feeling of ownership they have for the organization, and even their jobs in M\&A.

In particular, our moderated mediation model yields insights into a sense of possessiveness among employees and executives in M\&A, as opposed to simply having the desire or needing or feeling obliged to remain affiliated or using elements of an organization's identity to define oneself. In so doing, this paper accounts for the individual-organization relationship through feelings of ownership (and some of its consequences), which is unaccounted for especially in the existing models of commitment and identification in M\&A research (e.g. Hassett, 2012; Kroon et al., 2009). We also elaborated on two mediating variables in our proposed model (i.e., employees' commitment and involvement) that influence the positive relationship between acquired firm employees' psychological ownership and acquired firm employees' retention. Further, we elaborated on one moderating variable in our model (i.e., loss of acquired firm autonomy), that moderates the effect of acquired firm employees' psychological ownership on employees' commitment and involvement and, ultimately, acquired firm employees' retention.

Finally, we offered some suggestions on relevant methods for empirically testing the various propositions developed here, noted the limitations of our moderated mediation model, and showed directions for further development of our research. If our suggested psychological ownership perspective serves to encourage further intellectual exploration into understanding more fully how acquired employees and executives'

Rights statement: This is the authors' version of the article that has been accepted for publication in Human Resource Management Review and undergone full peer review but has not been through the copyediting, typesetting, pagination and proofreading process, which may lead to differences between this version and the Version of Record. 
retention - and for that matter M\&A performance - is impacted by underlying positive psychological concepts, then our efforts will have been worthwhile.

Acknowledgements: William Degbey acknowledges the Foundation for Economic Education and Marcus Wallenberg Foundation in Finland for their support of this research.

\section{References}

Ahammad, M. F., Glaister, K. W., Weber, Y., \& Tarba, S. Y. (2012). Top management retention in cross-border acquisitions: the roles of financial incentives, acquirer's commitment and autonomy. European Journal of International Management, 6(4), 458-480.

Aklamanu, A., Degbey, W.Y., \& Tarba, S.Y. (2016). The role of HRM and social capital configuration for knowledge sharing in post-M\&A integration: a framework for future empirical investigation. The International Journal of Human Resource Management, 27(22), 2790-2822.

Amiot, C. E., Terry, D. J., \& Callan, V. J. (2007). Status, equity and social identification during an inter-group merger: A longitudinal study. British Journal of Social Psychology. 46, 557-577.

Angwin, D.N. \& Meadows, M. (2015). New integration strategies for post-acquisition management. Long Range Planning, 48(4), 235-251.

Avey, J.B., Avolio, B.J., Crossley, C.D., \& Luthans, F. (2009). Psychological ownership: Theoretical extensions, measurement and relation to work outcomes. Journal of Organizational Behavior, 30(2), 173-191.

Barney, J. B. (1988). Returns to bidding firms in mergers and acquisitions: Reconsidering the relatedness hypothesis. Strategic Management Journal, 9(S1), 71-78.

Rights statement: This is the authors' version of the article that has been accepted for publication in Human Resource Management Review and undergone full peer review but has not been through the copyediting, typesetting, pagination and proofreading process, which may lead to differences between this version and the Version of Record. 
Baron, R.M. \& Kenny, D.A. (1986). The moderator-mediator variable distinction in social psychological research: Conceptual, strategic, and statistical considerations. Journal of Personality and Social Psychology, 51(6), 1173.

Bartels, J., Douwes, R., Jong, M., \& Pruyn, A. (2006). Organizational identification during a merger: Determinants of employees' expected identification with the new organization. British Journal of Management, 17(S1), S49-S67.

Bauer, F., \& Matzler, K. (2014). Antecedents of M\&A success: The role of strategic complementarity, cultural fit, and degree and speed of integration. Strategic Management Journal, 35(2), 269-291.

Baytos, L. (1986). The HR side of acquisition and divestiture, Human Resource Planning, 4, 167-175.

Bergh, D. D. (2001). Executive retention and acquisition outcomes: A test of opposing views on the influence of organizational tenure. Journal of Management, 27(5), 603-622.

Bernhard, F. \& O'Driscoll, M.P. (2011). Psychological ownership in small familyowned businesses: Leadership style and nonfamily-employees' work attitudes and behaviors. Group \& Organization Management, 36(3), 345384.

Bilgili, T. V., Calderon, C. J., Allen, D. G., \& Kedia, B. L. (2017). Gone With the Wind A Meta-Analytic Review of Executive Turnover, Its Antecedents, and Postacquisition Performance. Journal of Management, 43(6), 1966-1997.

Blau, P. M. (1964). Exchange and power in social life. New York: Wiley.

Bleeke, J. A. \& Daniels, L. K. (1985). After a deal is completed: How far and how fast to move? California Management Review. 30(Fall) 9-11.

Birkinshaw, J. (1999). Acquiring intellect: Managing the integration of knowledgeintensive acquisitions. Business Horizons, 42(3), 33-40.

Rights statement: This is the authors' version of the article that has been accepted for publication in Human Resource Management Review and undergone full peer review but has not been through the copyediting, typesetting, pagination and proofreading process, which may lead to differences between this version and the Version of Record. 
Birkinshaw, J., Bresman, H., \& Håkanson, L. (2000). Managing the post-acquisition integration process: How the human integration and task integration processes interact to foster value creation. Journal of Management Studies, 37, 395-425.

Bradley, J. \& Korn, D. (1981). Acquisition and corporate development. Lexington, MA: Lexington Books.

Brown, G., Lawrence, T. B., \& Robinson, S. L. (2005). Territoriality in organizations. Academy of Management Review, 30, 577-594.

Brown, M. \& Cregan, C. (2008). Organizational change cynicism: The role of employee involvement. Human Resource Management, 47(4), 667-686.

Brown, G., Crossley, C., \& Robinson, S. L. (2014). Psychological ownership, territorial behavior, and being perceived as a team contributor: The critical role of trust in the work environment. Personnel Psychology, 67(2), 463-485.

Buchko, A. A. (1993). The effects of employee ownership on employee attitudes: an integrated causal model and path analysis. Journal of Management Studies, 30(4), 633-657.

Buono, A. F. \& Bowditch, J. L. (1989). The human side of mergers and acquisitions. San Francisco, CA: Jossey-Bass.

Buono, A. F. \& Bowditch, J. L. (2003). Human side of mergers and acquisitions: Managing collisions between people and organizations. Washington, DC: Beard Books.

Butler, F. C., Perryman, A. A., \& Ranft, A. L. (2012). Examining the effects of acquired top management team turnover on firm performance post-acquisition: A meta-analysis. Journal of Managerial Issues, 12(1), 47-60.

Cannella, A. A. \& Hambrick, D. C. (1993). Effects of executive departures on the performance of acquired firms. Strategic Management Journal, 14(S1), 137-152.

Cartwright, S., Tytherleigh, M., \& Robertson, S. (2007). Are mergers always stressful? Some evidence from the higher education sector. European Journal of Work and Organizational Psychology, 16(4), 456-478.

Rights statement: This is the authors' version of the article that has been accepted for publication in

Human Resource Management Review and undergone full peer review but has not been through the copyediting, typesetting, pagination and proofreading process, which may lead to differences between this version and the Version of Record.

Please cite this article as: Degbey, W.Y., Rodgers, P., Kromah, M.D., \& Weber, Y. (in press). The impact of psychological ownership on employee retention in mergers and acquisitions, Human Resource Management Review. DOI: https://doi.org/10.1016/j.hrmr.2020.100745 
Cartwright, S. \& Cooper, C. L. (1990). The impact of mergers and acquisitions on people at work: Existing research and issues. British Journal of Management, 1(2), 65-76.

Cartwright, S. \& Cooper, C. L. (1993). The psychological impact of merger and acquisition on the individual: A study of building society managers. Human relations, 46(3), 327-347.

Christofferson, S. A., McNish, R. S. \& Sias, D. L. (2004). Where mergers go wrong. Perspectives on Corporate Finance and Strategy. McKinsey \& Company, $10,1-6$.

Colman, H.L. \& Lunnan, R. (2011). Organizational identification and serendipitous value creation in post-acquisition integration. Journal of Management, $37(3), 839-860$

Conte, M., \& Tannenbaum, A. S. (1978). Employee-owned companies: Is the difference measurable? Monthly Labor Review, 101(7), 23-28.

Cotton, J.L., Vollrath, D.A., Froggatt, K.L., Lengnick-Hall, M.L., \& Jennings, K.R. (1988). Employee participation: Diverse forms and different outcomes. Academy of Management review, 13(1), 8-22.

Coughlan, A. T., \& Schmidt, R. M. (1985). Executive compensation, management turnover, and firm performance: An empirical investigation. Journal of Accounting and Economics, 7(1-3), 43-66.

Datta, D. K., \& Grant, J. H. (1990). Relationships between type of acquisition, the autonomy given to the acquired firm, and acquisition success: An empirical analysis. Journal of Management, 16(1), 29-44.

Davis, G. F., \& Stout, S. K. (1992). Organizational theory and the market for corporate control: A dynamic analysis of the characteristics of large takeover targets, 1980-1990. Administrative Science Quarterly, 37(4), 605-633.

Dawkins, S. Tian, A. W, Newman, A. \& Martin, A. (2017). Psychological ownership: A review and research agenda. Journal of Organizational Behavior, $38(2), 163-183$.

Rights statement: This is the authors' version of the article that has been accepted for publication in Human Resource Management Review and undergone full peer review but has not been through the copyediting, typesetting, pagination and proofreading process, which may lead to differences between this version and the Version of Record. 
DeAngelo, H. \& DeAngelo, L. (1985). Managerial ownership of voting rights: a study of public corporations with dual classes of common stock. Journal of Finance, 14, 33-70.

Degbey, W. Y. (2016a). Why good things may not happen in knowledge-intensive acquisitions: The neglect of acquired firm's customers. In Y. Weber \& S. Tarba (Eds.). Mergers and Acquisitions, Entrepreneurship and Innovation (pp. 151-167). Emerald Group Publishing Limited.

Degbey, W. Y. (2016b). Customer retention in a cross-border acquisition: a single-case study of a knowledge-intensive firm. Turku, Finland: University of Turku-Annales Universitatis Turkuensis.

Degbey, W. Y. (2015). Customer retention: A source of value for serial acquirers. Industrial Marketing Management, 46, 11-23.

Degbey, W.Y. \& Ellis, K.M. (2019). Diaspora Networks in Cross-Border Mergers and Acquisitions. In: Elo M., Minto-Coy I. (eds), Diaspora Networks in International Business. Contributions to Management Science (pp. 407421). Cham: Springer.

Degbey W.Y. \& Ellis, K.M. (2017). Africa: An Emerging Context for Value Creation with Cross-Border Mergers and Acquisitions. In: Marinova S., Larimo J., Nummela N. (eds), Value Creation in International Business: An MNC Perspective (Vol. 1, pp. 163-195). UK: Palgrave Macmillan.

Degbey, W. Y. \& Hassett, M. E. (2016). Creating value in cross-border M\&As through strategic networks. In Tuselmann, H., Buzdugan, S., Cao, Q., Freund, D. and Golesorkhi, S. (eds), Impact of International Business: Challenges and Solutions for Policy and Practice (pp. 158-177). London: Palgrave Macmillan.

Dirks, K. T., Cummings, L. L., \& Pierce, J. L. (1996). Psychological ownership in organizations: Conditions under which individuals promote and resist change. In R. W. Woodman \& W. A. Pasmore (Eds.). Research in organizational change and development, 9, 1-23. Greenwich, CT: JAI Press.

Rights statement: This is the authors' version of the article that has been accepted for publication in Human Resource Management Review and undergone full peer review but has not been through the copyediting, typesetting, pagination and proofreading process, which may lead to differences between this version and the Version of Record. 
Dittmar, H. (1992). The social psychology of material possessions: To have is to be. New York: St. Martin's Press.

Edwards, M.R. (2005). Organizational identification: A conceptual and operational review. International Journal of Management Reviews, 7(4), 207-230.

Etzioni, A. (1991). The socio-economics of property. Journal of social behavior and personality, 6(6), 465-468.

Firth, M., Fung, P.M., \& Rui, O.M. (2006). Firm performance, governance structure, and top management turnover in a transitional economy. Journal of Management Studies, 43(6), 1289-1330.

French, J.L. \& Rosenstein, J. (1984). Employee ownership work attitudes, and power relationships. Academy of Management Journal, 27(4), 861-869.

Furby, L. (1978). Possession in humans: An exploratory study of its meaning and motivation. Social Behavior and Personality, 6(1), 49-65.

Gomes, E., Angwin, D. N., Weber, Y. \& Tarba, S.Y. (2013). Critical Success Factors through the Mergers and Acquisitions Process: Revealing Pre- and PostM\&A Connections for Improved Performance, Thunderbird International Business Review, 55(1), 13-35.

Gomes, E., Weber, Y., Brown, C., \& Tarba, S.Y. (2011). Mergers, Acquisitions and Strategic Alliances: Understanding the Process. Basingstoke: Palgrave Macmillan.

Greller, M. M. (2004). Managing feedback systems to facilitate change in acquisitions: The introduction of a model and explanation of its application. Human Resource Management Review, 13(4), 647-673.

Guest, D. (2002). Human resource management, corporate performance and employee wellbeing: Building the worker into HRM. Journal of Industrial Relations, 44(3), 335-358.

Hackman, J. R., \& Oldham, G. R. (1975). Development of the Job Diagnostic Survey. Journal of Applied Psychology, 60, 159-170.

Rights statement: This is the authors' version of the article that has been accepted for publication in Human Resource Management Review and undergone full peer review but has not been through the copyediting, typesetting, pagination and proofreading process, which may lead to differences between this version and the Version of Record. 
Hagedoorn, J. \& Hesen, G. (2007). Contract law and the governance of inter-firm technology partnerships - an analysis of different modes of partnering and their contractual implications. Journal of Management Studies, 44(3), $342-366$.

Hajro, A. (2015). Cultural influences and the mediating role of socio-cultural integration processes on the performance of cross-border mergers and acquisitions. The International Journal of Human Resource Management, 26, 192-215.

Hambrick, D. C., \& Cannella, A. A. (1993). Relative standing: A framework for understanding departures of acquired executives. Academy of Management Journal, 36(4), 733-762.

Hammer, T. H., Landau, J. C., \& Stern, R. N. (1981). Absenteeism when workers have a voice: The case of employee ownership. Journal of Applied Psychology, $66(5), 561-573$.

Han, T. S., Chiang, H. H., \& Chang, A. (2010). Employee participation in decision making, psychological ownership and knowledge sharing: mediating role of organizational commitment in Taiwanese high-tech organizations. The International Journal of Human Resource Management, 21(12), 22182233.

Haspeslagh, P.C. \& Jemison, D. B. (1991). Managing acquisitions - creating value through corporate renewal. New York: The Free Press.

Hassett, M. (2012). Organizational commitment in acquisitions. Advances in Mergers and Acquisitions, 10, 19-38.

Hogg, M. A. \& Terry, D. J. (2000). Social identity and self-categorization process in organizational contexts. Academy of Management Review, 25, 121-140.

Humpal, J.J. (1971). Organizational Marriage Counselling: A First Step. Journal of Applied Behavioral Science, 7, 103-109

Jarrell, G.A., Brickley, J.A., \& Netter, J.M. (1988). The market for corporate control: the empirical evidence since 1980. Journal of Economic Perspectives, 2,

Rights statement: This is the authors' version of the article that has been accepted for publication in Human Resource Management Review and undergone full peer review but has not been through the copyediting, typesetting, pagination and proofreading process, which may lead to differences between this version and the Version of Record. 
$49-68$.

Jensen, M.C. \& Ruback, R. (1983). The market for corporate control: the scientific evidence. Journal of Financial Economics, 11, 5-50.

Jimmieson, N. L. \& White, K. M. (2011). Predicting employee intentions to support organizational change: An examination of identification processes during a re-brand. British Journal of Social Psychology, 50, 331-341.

Kelly, J., Cook, C, \& Spitzer, D. (2003). Unlocking Shareholder Value: The Keys to Success-Mergers and acquisitions: A Global Research Report, KPMG, Annapolis.

King, D. R., Bauer, F., Weng, Q., Schriber, S., \& Tarba, S. (2019). What, when, and who: Manager involvement in predicting employee resistance to acquisition integration. Human Resource Management. DOI:

$10.1002 / \mathrm{hrm} .21973$

Klendauer, R., \& Deller, J. (2009). Organizational justice and managerial commitment in corporate mergers. Journal of Managerial Psychology, 24(1), 29-45.

Krishnan, H.A., Miller, A., \& Judge, W.Q. (1997). Diversification and top management team complementarity: Is performance improved by merging similar or dissimilar teams? Strategic Management Journal, 18, 361-374.

Kroon, D. P., \& Noorderhaven, N. G. (2018). The role of occupational identification during post-merger integration. Group \& Organization Management, 43(2), 207-244.

Kroon, D. P., Noorderhaven, N. G., \& Leufkens, A. S. (2009). Organizational identification and cultural differences: Explaining employee attitudes and behavioral intentions during postmerger integration. In C. L. Cooper \& S. Finkelstein (Eds.), Advances in mergers and acquisitions (Vol. 8, pp. 1942). Bingley, UK: Emerald Group.

Krug, J. A., \& Shill, W. (2008). The big exit: executive churn in the wake of M\&As. Journal of Business Strategy, 29(4), 15-21.

Rights statement: This is the authors' version of the article that has been accepted for publication in Human Resource Management Review and undergone full peer review but has not been through the copyediting, typesetting, pagination and proofreading process, which may lead to differences between this version and the Version of Record.

Please cite this article as: Degbey, W.Y., Rodgers, P., Kromah, M.D., \& Weber, Y. (in press). The impact of psychological ownership on employee retention in mergers and acquisitions, Human Resource Management Review. DOI: https://doi.org/10.1016/j.hrmr.2020.100745 
Krug, J. A. (2003). Executive turnover in acquired firms: A longitudinal analysis of long term integration effects. Paper presented at the academy of management meeting.

Krug, J. A. \& Hegarty, W. H. (2001). Predicting who stays and leaves after an acquisition: A study of top managers in multinational firms. Strategic Management Journal, 22(2), 185-196.

Krug, J.A. \& Hegarty, W.H. (1997). Postacquisition turnover among U.S. top management teams: an analysis of the effects of foreign vs. domestic acquisitions of U.S. targets. Strategic Management Journal, 18, 667-675.

Krug, J.A. \& Nigh, D. (1998). Top management turnover: a comparative analysis of the effects of foreign versus domestic acquisitions of U.S. firms. In: D. Woodward \& D. Nigh (Eds.). Foreign investment in the United States: beyond us and them. New York: Quorum Books.

Krug, J. A. \& Aguilera, R.V. (2005). Top management team turnover in mergers and acquisitions. In C. L. Cooper \& S. Finkelstein (Eds.). Advances in Mergers \& Acquisitions, 4, 123-154.

Krug, J. A., Wright, P., \& Kroll, M. J. (2014). Top management turnover following mergers and acquisitions: solid research to date but still much to be learned. The Academy of Management Perspectives, 28(2), 147-163.

Kubzansky, P.E. \& Druskat, V.U. (1993). Psychological sense of ownership in the workplace: Conceptualization and measurement. In annual meeting of the American Psychological Association, Toronto, Ontario.

Kusstatscher, V. \& Cooper, C.L. (2005). Managing emotions in mergers and acquisitions. Edward Elgar Publishing.

Lawler, E.E. \& Hall, D.T. (1970). Relationship of job characteristics to job involvement, satisfaction, and intrinsic motivation. Journal of Applied psychology, 54(4), p.305.

Rights statement: This is the authors' version of the article that has been accepted for publication in Human Resource Management Review and undergone full peer review but has not been through the copyediting, typesetting, pagination and proofreading process, which may lead to differences between this version and the Version of Record. 
Lee, D., Kim, K., Kim, T. G., Kwon, S., \& Cho, B. (2013). How and when organizational integration efforts matter in South Korea: a psychological process perspective on the post-merger integration. The International Journal of Human Resource Management, 24(5), 944-965.

Long, R. J. (1978). The effects of employee ownership on organizational identification, job attitudes and organizational performance: A tentative framework and empirical findings. Human Relations, 31, 29-48.

Lubatkin, M., Schweiger, D., \& Weber, Y. (1999). Top management turnover in related M\&As: An additional test of the theory of relative standing. Journal of Management, 25, 55-74.

Mäkelä, K. \& Brewster, C. (2009). Interunit interaction contexts, interpersonal social capital, and the differing levels of knowledge sharing. Human Resource Management, 48, 591-613.

Manne, H. G. (1965). Mergers and the market for corporate control. The Journal of Political Economy, 73(2), 110-120.

Marks, M. L. \& Mirvis, P. H. (2011). A framework for the human resources role in managing culture in mergers and acquisitions. Human Resource Management, 50, 859-877.

Mathieu, J. E. \& Zajac, D. M. (1990). A review and meta-analysis of the antecedents, correlates, and consequences of organizational commitment. Psychological Bulletin, 108 (2), 171-194.

Mayhew, M.G., Ashkanasy, N.M., Bramble, T., \& Gardner, J. (2007). A study of the antecedents and consequences of psychological ownership in organizational settings. The Journal of Social Psychology, 147(5), 477500.

McNamara, G. M., Haleblian, J., \& Dykes, B. J. (2008). The performance implications of participating in an acquisition wave: Early mover advantages, bandwagon effects, and the moderating influence of industry characteristics and acquirer tactics. Academy of Management Journal, 51(1), 113-130.

Rights statement: This is the authors' version of the article that has been accepted for publication in Human Resource Management Review and undergone full peer review but has not been through the copyediting, typesetting, pagination and proofreading process, which may lead to differences between this version and the Version of Record. 
Meglio, O., King, D. R., \& Risberg, A. (2015). Improving acquisition outcomes with contextual ambidexterity. Human Resource Management, 54(S1), 29-43.

Meyer, J. P., \& Allen, N. J. (1991). A three-component conceptualization of organizational commitment. Human Resource Management Review, 1(1), 61-89.

Mowday, R. T., Steers, R. M., \& Porter, L. W. (1982). Employee-Organizational Linkages: The Psychology of Commitment, Turnover and Absenteeism. New York: Academic Press.

Nyberg, A. J., Fulmer, I. S., Gerhart, B., \& Carpenter, M. A. (2010). Agency theory revisited: CEO return and shareholder alignment. Strategic Management Journal, 53(5), 1029-1049.

O’Driscoll, M.P., Pierce, J.L., \& Coghlan, A.M. (2006). The psychology of ownership work environment structure, organizational commitment, and citizenship behaviors. Group \& Organization Management, 31(3), 388-416.

O'Reilly, C. E. (2002). The wrong kind of ownership. Across the Board, 39(5), 19-20. Paruchuri, S., Nerkar, A., \& Hambrick, D. C. (2006). Acquisition integration and productivity losses in the technical core: Disruption of inventors in acquired companies. Organization Science, 17(5), 545-562.

Parker, S. K., Wall, T. D., \& Jackson, P. R. (1997). “That's not my job”: Developing flexible employee work orientations. Academy of Management Journal, 40, 899-929.

Patchen, M. (1970). Participation, achievement, and involvement on the job. Englewood Cliffs, New Jersey: Prentice-Hall.

Petrescu, A. I. \& Simmons, R. (2008). Human resource management practices and workers' job satisfaction. International Journal of Manpower, 29, 651667.

Pierce, J. L., Rubenfeld, S. A., \& Morgan, S. (1991). Employee ownership: A conceptual model of process and effects. Academy of Management Review, 16, 121-144.

Rights statement: This is the authors' version of the article that has been accepted for publication in Human Resource Management Review and undergone full peer review but has not been through the copyediting, typesetting, pagination and proofreading process, which may lead to differences between this version and the Version of Record. 
Pierce, J. L., O'driscoll, M.P., \& Coghlan, A. M. (2004). Work environment structure and psychological ownership: The mediating effects of control. The Journal of Social Psychology, 144(5), 507-534.

Pierce, J. L., Kostova, T., \& Dirks, K. T. (2003). The state of psychological ownership: Integrating and extending a century of research. Review of General Psychology, 7(1), 84.

Pierce, J. L., Kostova, T., \& Dirks, K. T. (2001). Toward a theory of psychological ownership in organizations. Academy of Management Review, 26(2), 298310.

Pitts, R.A. (1976). Diversification strategies and organizational policies of large diversified firms. Journal of Economics Business, 28, 181-188.

Preacher, K. J. \& Hayes, A. F. (2008). Contemporary approaches to assessing mediation in communication research. In A. F. Hayes, M. D. Slater, \& L. B. Snyder (Eds). The Sage Sourcebook of Advanced Data Analysis Methods for Communication Research (pp. 13-54). Thousand Oaks, CA: Sage.

Preacher, K. J., Rucker, D. D., \& Hayes, A. F. (2007). Addressing moderated mediation hypotheses: theory, methods, and prescriptions. Multivariate Behavioral Research, 42(1), 185-227

Puranam, P., Singh, H., \& Zollo, M. (2006). Organizing for innovation: Managing the coordination-autonomy dilemma in technology acquisitions. Academy Management Journal, 49(2) 263-280.

Quinn, R. E. (1996). Deep change: Discovering the leader within. San Francisco, CA: Jossey-Bass.

Ranft, A. L. \& Lord, M. D. (2000) Acquiring new knowledge: The role of retaining human capital in acquisitions of high-tech firms. The Journal of High Technology Management Research, 11(2), 295-319.

Ranft, A. (2006). Knowledge preservation and transfer during post-acquisition integration. Advances in mergers and acquisitions, 5(1), 51-67.

Rights statement: This is the authors' version of the article that has been accepted for publication in Human Resource Management Review and undergone full peer review but has not been through the copyediting, typesetting, pagination and proofreading process, which may lead to differences between this version and the Version of Record. 
Raukko, M. (2009). Organizational commitment during organizational changes: A longitudinal case study on acquired key employees. Baltic Journal of management, 4(3), 331-352.

Rees, C. \& Edwards, T. (2009). Management strategy and HR in international mergers: Choice, constraint and pragmatism. Human Resource Management Journal, 19, 24-39.

Reus, T. (2015). A psychological lens on the acquisition process. RSM DiscoveryManagement Knowledge, 2015(2), 17-19.

Rooney, D., Paulsen, N., Callan, V.J., Brabant, M., Gallois, C., \& Jones., E. (2010). A

New Role for Place Identity in Managing Organizational Change.

Management Communication Quarterly, 24(1), 44-73.

Rousseau, D. M., \& Shperling, Z. (2003). Pieces of the action: Ownership and the changing employment relationship. Academy of Management Review, 28(4), 553-570.

Sarala, R. M., Junni, P., Cooper, C. L., \& Tarba, S. Y. (2016). A sociocultural perspective on knowledge transfer in mergers and acquisitions. Journal of Management, 42(5), 1230-1249.

Schoenberg, R. (2006). Measuring the performance of corporate acquisitions: an empirical comparison of alternative metrics, British Journal of Management, 17, 361-370.

Schuler, R. S., Jackson, S. E., \& Luo, Y. (2004). Managing human resources in crossborder alliances. London: Routledge.

Schweiger, D. M., \& Weber, Y. (1989). Strategies for managing human resources during mergers and acquisitions: An empirical investigation. Human Resource Planning, 12, 69-86.

Schweiger, D.M. \& Goulet, P.K. (2000). Integrating mergers and acquisitions: an international research review, Advances in Mergers and Acquisitions, 1, $61-91$.

Siehl, C., Smith, D., \& Omura, A. (1990). After the merger: Should executives stay or go? Executive 4(1) 50-61.

Rights statement: This is the authors' version of the article that has been accepted for publication in Human Resource Management Review and undergone full peer review but has not been through the copyediting, typesetting, pagination and proofreading process, which may lead to differences between this version and the Version of Record.

Please cite this article as: Degbey, W.Y., Rodgers, P., Kromah, M.D., \& Weber, Y. (in press). The impact of psychological ownership on employee retention in mergers and acquisitions, Human Resource Management Review. DOI: https://doi.org/10.1016/j.hrmr.2020.100745 
Sinkovics, R., Zagelmeyer, S., \& Kusstatscher, V. (2011). Between merger and syndrome: The intermediary role of emotions in four cross-border M\&As. International Business Review, 20(1), 27-47.

Staw, B. M. (1991). Dressing up like an organization: When psychological theories can explain organizational action. Journal of Management, 17(4), 805-819.

Steel, P. \& Konig, C. J. (2006). Integrating theories of motivation. Academy of Management Review, 31, 889-913.

Swart, J. \& Kinnie, N. (2003). Sharing knowledge in knowledge-intensive firms. Human Resource Management Journal, 13, 60-75.

Tarba, S. Y., Ahammad, M. F., Junni, P., Stokes, P., \& Morag, O. (2019). The impact of organizational culture differences, synergy potential, and autonomy granted to the acquired high-tech firms on the M\&A performance. Group \& Organization Management, 44(3), 483-520.

Teerikangas, S. (2012). Dynamics of Acquired Firms Pre-Acquisition Employee Reactions. Journal of Management, 38, 599-639.

Thanos, I. C. \& Papadiakis, V. M. (2012). The use of accounting- based measures for measuring M\&A performance: a review of five decades of research, Advances in Mergers and Acquisitions, 10, 103-120.

Ullrich, J., Wieseke J., \& van Dick, R. (2005). Continuity and change in mergers and acquisitions: A social identity case study of a German industrial merger. Journal of Management Studies 42(8), 1549-1569.

Vandewalle, D., Van Dyne, L., \& Kostova, T. (1995). Psychological ownership: An empirical examination of its consequences. Group \& Organization Management, 20(2), 210-226.

Van Dick, R., Ullrich, J., \& Tissington, P. A. (2006). Working Under a Black Cloud: How to Sustain Organizational Identification after a Merger. British Journal of management, 17(S1), S69-S79.

Rights statement: This is the authors' version of the article that has been accepted for publication in Human Resource Management Review and undergone full peer review but has not been through the copyediting, typesetting, pagination and proofreading process, which may lead to differences between this version and the Version of Record. 
Van Dyne, L. \& Pierce, J. L. (2004). Psychological ownership and feelings of possession: three field studies predicting employee attitudes and organizational citizenship behavior. Journal of Organizational Behavior, 25(4), 439-459.

Van Knippenberg, D., Van Knippenberg, B., Monden, L., \& Lima, F. (2002). Organizational identification after a merger: A social identity perspective. British Journal of Social Psychology, 41(2), 233-252.

Vasilaki, A., Tarba, S., Ahammad, M. F., \& Glaister, A. J. (2016). The moderating role of transformational leadership on HR practices in M\&A integration. The International Journal of Human Resource Management, 27(20), 24882504.

Very, P., Lubatkin, M., Calori, R., \& Veiga, J. (1997). Relative standing and the performance of recently acquired European firms. Strategic Management Journal, 18, 593-614.

Vroom, V. (1964). Work and Motivation. New York: Wiley.

Walsh, J. P. (1988). Top management turnover following mergers and acquisitions. Strategic Management Journal, 9(2), 173-183.

Waldman, D., \& Javidan, M. (2009). Alternative forms of charismatic leadership in the integration of mergers and acquisitions. The Leadership Quarterly, 20, $130-142$.

Walsh, J. P. (1989). Doing a deal: Merger and acquisition negotiations and their impact upon target company top management turnover. Strategic Management Journal, 10, 307-322.

Walsh, J.P. \& Ellwood, J.W. (1991). Mergers, acquisitions, and the pruning of managerial deadwood. Strategic Management Journal, 12, 201-217.

Walsh, J.P. \& Kosnik, R.D. (1993). Corporate raiders and their disciplinary role in the market for corporate control. Academy of Management Journal, 36, 671700.

Weber, Y. (2012). Introduction. In Y. Weber (Ed.). Handbook of research on mergers

Rights statement: This is the authors' version of the article that has been accepted for publication in Human Resource Management Review and undergone full peer review but has not been through the copyediting, typesetting, pagination and proofreading process, which may lead to differences between this version and the Version of Record. 
and acquisitions: ix-xix. Cheltenham, UK: Edward Elgar.

Weber, Y., Tarba, S. Y., \& Öberg, C. (2014). A comprehensive guide to mergers \& acquisitions: Managing the critical success factors across every stage of the $M \& A$ process. Upper Saddle River, New Jersey: Pearson \& Financial Times Press.

Weber, Y. \& Tarba, S.Y. (2012). Mergers and acquisitions process: The use of corporate culture analysis, Cross-Cultural Management: An International Journal, 19, 288-303.

Weber, Y. \& Drori, I. (2011). Integrating organizational and human behavior perspectives on mergers and acquisitions: Looking inside the black box. International Studies of Management \& Organization, 41(3), 76-95.

Weber, Y., \& Fried, Y. (2011). Guest Editors' Note: The role of HR practices in managing culture clash during the postmerger integration process. Human Resource Management, 50(5), 565-570.

Weber, Y., Tarba, S. Y., \& Reichel, A. (2011). A model of the influence of culture on integration approaches and international mergers and acquisitions performance. International Studies of Management \& Organization, 41(3), 10-28.

Weber, Y., \& Tarba, S.Y. (2010). Human resource practices and performance of M\&A in Israel. Human Resource Management Review, 20, 203-211.

Weber, Y., Yedidia Tarba, S., \& Reichel, A. (2009). International mergers and acquisitions performance revisited-the role of cultural distance and post. In Advances in Mergers and Acquisitions (pp. 1-17). Emerald Group Publishing Limited.

Rights statement: This is the authors' version of the article that has been accepted for publication in Human Resource Management Review and undergone full peer review but has not been through the copyediting, typesetting, pagination and proofreading process, which may lead to differences between this version and the Version of Record. 
Wilpert, B. (1991). Property, ownership, and participation: on the growing contradictions between legal and psychological concepts. In R. Russell, \& V. Rus (Eds.). International handbook of participation in organizations: For the study of organizational democracy, co-operation, and self-management (Vol. 2, pp. 149-164). New York: Oxford University Press.

Xing, Y., Liu, Y., Tarba, S. Y., \& Cooper, C. L. (2016). Intercultural influences on managing African employees of Chinese firms in Africa: Chinese managers' HRM practices. International Business Review, 25(1), 28-41.

Zhang, J., Ahammad, M. F., Tarba, S., Cooper, C. L., Glaister, K. W., \& Wang, J. (2015). The effect of leadership style on talent retention during merger and acquisition integration: Evidence from China. The International Journal of Human Resource Management, 26(7), 1021-1050.

Rights statement: This is the authors' version of the article that has been accepted for publication in Human Resource Management Review and undergone full peer review but has not been through the copyediting, typesetting, pagination and proofreading process, which may lead to differences between this version and the Version of Record. 